Izabela Zawiślińska

\title{
PROBLEM DŁUGU PUBLICZNEGO W PAŃSTWACH UNII GOSPODARCZEJ I WALUTOWEJ
}

\section{Wprowadzenie}

Dług publiczny i kwestia narastania zadłużenia państw nie jest zjawiskiem nowym. Jak wskazuje Jacques Attali w książce Zachód 10 lat przed totalnym bankructwem?, historia długu jest ściśle związana z historią państwa. W początkowym okresie dług był osobistym zobowiązaniem monarchy, który go zaciągał, i wygasał wraz z jego śmiercią lub też w wyniku innych działań, przykładowo wypędzenia wierzyciela czy pozbawienia go wolności lub życia. Z czasem jednak, wraz z uznaniem suwerennej ciągłości władzy następuje uznanie ciągłości spłaty zobowiązań zawartych przez władcę w imieniu danego państwa. Dzięki tej zmianie, a więc uznaniu ciągłości znaczenia królewskiego słowa, istnieje możliwość zaciągania stałych pożyczek przez monarchę na pokrycie rosnących potrzeb pożyczkowych, których nie można sfinansować ściąganymi podatkami. Kolejnym krokiem na drodze ewolucji długu publicznego, z którym stykamy się współcześnie, było odejście od spłaty całości zaciągniętych pożyczek na rzecz regulowania jedynie zobowiązań z tytułu odsetek, a następnie refinansowanie długu.

Jeśli więc przyjmiemy, iż państwo posiada długi, to czy podobnie jak inne podmioty gospodarcze - prywatni dłużnicy - może ono zbankrutować? Początkowo w kwestii tej panowało przekonanie, że państwo nie może zbankrutować. Obecnie pogląd ten uległ jednak ewolucji. Niemniej należy podkreślić, że rozumienie bankructwa państwa ma inny charakter niż pozostałych podmiotów. W przypadku konkretnych państw uznaje się, iż bankructwo (faktyczna niewypłacalność, bez konieczności jej deklaratywnego potwierdzenia przez władze danego państwa) to sytuacja, w której państwo zawiesza lub choćby zmienia warunki spłaty zobowiązań krajowych i/lub zagranicznych na mniej korzystne dla wierzycieli. Co oznacza, iż państwo zamierza oddać mniej niż wynosi dług lub w innych terminach, niż zostało ustalone, albo w grę wchodzi jedno i drugie ${ }^{1}$. Należy zwrócić uwagę, że bankructwo państwa może mieć charakter zarówno zewnętrzny, jak i wewnętrzny. Współczesne

\footnotetext{
1 Definicja bankructwa państwa za Joachimem Osińskim.
} 
dyskusje poświęcone tej problematyce koncentrują się przede wszystkim na aspekcie bankructwa zewnętrznego. W dużej mierze wynika to $\mathrm{z}$ faktu, iż prawdopodobieństwo jego wystąpienia jest większe oraz że rodzi ono poważne skutki dla społeczności międzynarodowej. Nie oznacza to oczywiście, że bankructwo wewnętrzne państwa jest „lepsze” niż zewnętrzne. Można nawet postawić tezę, że jest bardziej dotkliwe dla społeczeństwa i występuje zazwyczaj po bankructwie zewnętrznym. Najczęściej jest też traktowane jako ostateczność. Oznacza bowiem, że państwo nie jest w stanie wywiązywać się ze swoich zobowiązań wobec własnych obywateli, w tym z funkcji, które powinno pełnić. Bankructwo wewnętrzne rodzi wiele negatywnych następstw choćby w postaci zubożenia obywateli, a także ograniczenia aktywności międzynarodowej i utraty wiarygodności. Również koszty przezwyciężenia tego typu bankructwa są dużo większe. Bankructwo zewnętrzne związane z restrukturyzacją długu podważa zaufanie i wiarygodność międzynarodową, jednak przynajmniej częściowo koszty rozkładane są na podmioty zewnętrzne. W dotychczasowej historii wśród państw demokratycznych częściej występowało bankructwo zewnętrzne. Władza chętniej informowała o tym, że zawiesza lub zmienia warunki spłaty zobowiązań podmioty zagraniczne niż swoich obywateli - wyborców. Nie oznacza to oczywiście, że nie mieliśmy do czynienia z przypadkami bankructwa wewnętrznego w przeszłości. Jak wynika $\mathrm{z}$ tabeli 1, do tego typu zjawisk dochodziło nawet po 1970 roku w państwach znajdujących się niemal na wszystkich kontynentach.

Tabela 1. Wybrane przykłady bankructwa wewnętrznego (niewywiązania się z długu krajowego) po 1970 roku

\begin{tabular}{|l|c|l|c|}
\hline \multicolumn{1}{|c|}{ Państwo } & Rok & \multicolumn{1}{c|}{ Państwo } & Rok \\
\hline Angola & $1976-1992$ & Chorwacja & $1993-1996$ \\
\hline Kamerun & 2002 & Kuwejt & $1990-1991$ \\
\hline Kongo Kinszasa & 2004 & Rosja & $1998-1999$ \\
\hline Gabon & 1979 & Ukraina & $1998-2000$ \\
\hline Ghana & $1999-2005,1982,1979$ & Argentyna & $1982,1989-1990,2002-2005$ \\
\hline Liberia & $1989-2006$ & Boliwia & 1982 \\
\hline Madagaskar & 2002 & Brazylia & $1986-1998,1990$ \\
\hline Mozambik & 1980 & Dominikana & $1975-2001$ \\
\hline Rwanda & 1995 & Ekwador & 1999 \\
\hline Sierra Leone & $1997-1998$ & Salwador & $1981-1996$ \\
\hline Sudan & 1991 & Grenada & $1982-2005$ \\
\hline Mongolia & $1997-2000$ & Meksyk & $1988-1998$ \\
\hline Myanmar (Birma) & 1984,1987 & Panama & 1985 \\
\hline Sri Lanka & 1996 & Peru & 2006 \\
\hline Wietnam & 1975 & Zimbabwe & \\
\hline Wyspy Salomona & $1995-2004$ & & \\
\hline
\end{tabular}

Źródło: C.M. Reinhart, K.S. Rogoff, This time is Different. Eight Centuries of Financial Folly, Princeton University Press, Princeton 2009, s. 112-116; T. Gruszecki, Świat na długu, Wydawnictwo KUL, Lublin 2012, s. 215-216. 
Za wzrost zainteresowania bankructwem zewnętrznym oprócz globalnego wymiaru długu przemawia także zmiana jego struktury. Coraz większa grupa państw finansuje długotrwałe nierównowagi budżetowe i bilansu handlowego poprzez zaciąganie zobowiązań za granicą. Tendencja ta obserwowana jest nie tylko $\mathrm{w}$ grupie państw rozwijających się, ale także wysoko rozwiniętych, w tym należących do Unii Gospodarczej i Walutowej. Do państw o największym udziale publicznego długu zagranicznego w relacji do całkowitego zadłużenia należą m.in. Austria (ponad 80\%), Portugalia (ponad 75\%), Irlandia, Grecja, Holandia (ponad 70\%), Francja (ponad 65\%), a także Belgia i Włochy. Niemcy i Hiszpania należą do grupy państw, w których nieznacznie, ale jednak przeważa dług publiczny zaciągnięty u obywateli tych państw w porównaniu $z$ długiem zaciągniętym u cudzoziemców. Wśród państw należących do Unii Europejskiej zaledwie nieco powyżej 30\% udział długu zagranicznego w całości długu publicznego występuje w Wielkiej Brytanii i Szwecji. Ciekawa sytuacja w tym kontekście występuje natomiast w Japonii, gdzie około 93\% długu znajduje się w rękach krajowych gospodarstw domowych i instytucji finansowych, mimo że jest on od wielu lat nisko oprocentowany ${ }^{2}$. Zapewnia to jej, z jednej strony, bezpieczeństwo w postaci znaczącego uniezależnienia się od zmian wyceny japońskiego długu na światowych rynkach, z drugiej jednak może spowodować katastrofalne skutki wywołane ewentualnym bankructwem wewnętrznym. Należy także zwrócić uwagę, że na wzrost skali długu zewnętrznego istotny wpływ ma dług prywatny, który w pewnych okolicznościach jest upaństwowiany. Jak wynika z tabeli 2, w przypadku wielu państw, także należących do strefy euro, łączny dług zewnętrzny w relacji do PKB znacznie przekracza poziom długu publicznego. Jest tak choćby w Irlandii, Hiszpanii, Portugalii, ale również we Francji czy w Niemczech.

Tabela 2. Dług publiczny i łączny dług zagraniczny wybranych państw w relacji do PKB

\begin{tabular}{|l|c|c|l|c|c|}
\hline \multicolumn{1}{|c|}{ Państwo } & $\begin{array}{c}\text { Dług publiczny } \\
\text { jako \% PKB }\end{array}$ & $\begin{array}{c}\text { Dług zagraniczny } \\
\text { ogółem jako \% PKB }\end{array}$ & \multicolumn{1}{|c|}{ Państwo } & $\begin{array}{c}\text { Dług publiczny } \\
\text { jako \% PKB }\end{array}$ & $\begin{array}{c}\text { Dług zagraniczny } \\
\text { ogółem jako \% PKB }\end{array}$ \\
\hline W. Brytania & 88,75 & 496,36 & USA & 72,72 & 100,71 \\
\hline Francja & 86,15 & 283,29 & Kanada & 81,19 & 91,64 \\
\hline Niemcy & 96,46 & 212,06 & Japonia & 196,55 & 55,98 \\
\hline Irlandia & 168,66 & 1262,23 & Argentyna & 38,22 & 35,74 \\
\hline Włochy & 118,53 & 167,47 & Brazylia & 59,52 & 21,17 \\
\hline Portugalia & 104,71 & 261,71 & Meksyk & 34,04 & 42,54 \\
\hline Hiszpania & 72,86 & 238,82 & Chiny & 13,56 & 10,87 \\
\cline { 3 - 6 } & & & Indie & 39,02 & 25,23 \\
\hline
\end{tabular}

Źródło: US debtclock.org (26.08.2012).

2 T. Gruszecki, Świat na długu, Wydawnictwo KUL, Lublin 2012, s. 43. 
W przypadku państw rozwijających się niewielka skala zadłużenia zagranicznego sektora prywatnego wynika w dużej mierze z ograniczonej zdolności kredytowej tych podmiotów na rynkach międzynarodowych, a także niechęci tych rynków do udzielania kredytów ze względu na wcześniejsze złe doświadczenia. Tak więc relatywnie dobra sytuacja tych państw z punktu widzenia skali zadłużenia zagranicznego nie zawsze wynika ze świadomej i celowej polityki zarówno instytucji publicznych, jak i podmiotów prywatnych. Negatywne doświadczenia z przeszłości tym razem mogą stanowić czynnik wzmacniający pozycję tych państw na arenie międzynarodowej. Można jednak, odnosząc się do opinii na temat przyszłej roli państw rozwijających się w kontekście rozwiązania kryzysu zadłużeniowego, zastanowić się nad zasadnością głoszonych ostatnio pewnych tez czy poglądów. Nie można bowiem zapominać, iż w dłuższej perspektywie czasowej szczególnie istotne znaczenie będzie miała solidność podstaw zarówno gospodarczych, jak i politycznych, stabilność oraz trwałość pewnych struktur demokratycznych, poszanowanie i przestrzeganie zasad państwa prawnego, a także zaufanie nie tylko wewnętrzne czy regionalne, ale głównie szerszej społeczności międzynarodowej. Z tym wszystkim w ostatnich latach w przypadku wielu państw rozwijających się bywało nie najlepiej. Ponadto, jak wskazują badania przeprowadzone przez Carmen M. Reinhart i Kennetha S. Rogoffa, państwa te cierpią na tzw. syndrom nietolerancji długu. Oznacza on, że mogą one mieć problemy $\mathrm{z}$ wypłacalnością zewnętrzną, a w konsekwencji również wewnętrzną nawet przy stosunkowo niskich wskaźnikach długu w relacji do dochodu narodowego. Tak więc przy poziomie długu zagranicznego, z którym radzą sobie państwa rozwinięte, państwa rozwijające się popadają w poważne kłopoty. Przykładowo w 1982 roku Meksyk zawiesił spłatę zadłużenia zagranicznego przy poziomie długu wynoszącym $46 \%$ PKB, a Argentyna 55,1\% PKB. Brazylia uczyniła to samo w 1983 roku, mając dług na poziomie 50\% PKB. Jeszcze wyraźniejsze przypadki niskiej tolerancji długu przez rynki międzynarodowe wobec państw rozwijających się stanowią Chile i Ekwador. W tym pierwszym państwie kryzys zawieszenia spłaty długu nastąpił w 1972 roku przy długu na poziomie 31\% PKB, natomiast Ekwador zawiesił spłatę zadłużenia zagranicznego w 2008 roku, gdy jego dług wynosił zaledwie 20\% $\mathrm{PKB}^{3}$. Na tej podstawie Carmen M. Reinhart i Kenneth S. Rogoff postawili tezę, że poszczególne państwa, a w zasadzie ich grupy cechują się różnym poziomem tolerancji zadłużenia. Przyjmowany powszechnie, także w odniesieniu do państw strefy euro, poziom $60 \%$ PKB w odniesieniu do długu publicznego nie ma racjonalnych podstaw bycia wartością graniczną dla państw rozwiniętych. Doświadczenia wielu państw w ostatnich

\footnotetext{
3 Por. C.M. Reinhart, K.S. Rogoff, This time is Different. Eight Centuries of Financial Folly, Princeton University Press, Princeton 2009, s. 23.
} 
dziesięcioleciach pokazują, że potrafią one sobie radzić z wyższym poziomem zadłużenia. Za przykład może posłużyć tu Japonia, której dług od lat i to wyraźnie przekracza 100\% PKB, a ostatnio prognozuje się przekroczenie granicy 200\% PKB. Nie oznacza to oczywiście, że konkluzją ich badań jest to, aby państwa rozwinięte zadłużały się bez ograniczeń, a problem niewypłacalności jest tylko i wyłącznie domeną państw rozwijających się. Sugerują jedynie, aby oficjalnie przesunąć próg tolerancji zadłużenia dla państw rozwiniętych na poziom $90 \%$ PKB. Nie należy bowiem tworzyć nierealistycznych założeń, strategii i programów, których w nowych uwarunkowaniach, w oderwanej w dużej mierze od sfery realnej współczesnej gospodarce światowej nie da się realizować czy przestrzegać. Należy do problematyki długu podchodzić realistycznie i modernizować nie tylko koncepcje teoretyczne, ale także strategie, które mają być realizowane w przyszłości. Natomiast dla państw rozwijających się proponują pozostawić próg tolerancji długu na poziomie 60\% PKB.

Reasumując, jak wskazują Carmen M. Reinhart i Kenneth S. Rogoff w książce This time is Different. Eight Centuries of Financial Folly, potencjalne bankructwa państw, w tym przede wszystkim zewnętrzne, na początku XXI wieku nie będą niczym nowym ani nadzwyczajnym. W okresie między 1300 a 1799 rokiem w samej tylko Europie mieliśmy do czynienia z 19 bankructwami, w tym osiem razy zbankrutowała Francja, a sześć Hiszpania ${ }^{4}$. Kolejne lata owocowały dalszymi bankructwami pojedynczych państw, jak również ich grup w regionie. Były one bardzo często następstwem wzrostu skali zadłużenia publicznego, które było bezpośrednim skutkiem zjawisk kryzysowych występujących w gospodarce lub jej otoczeniu, a przede wszystkim kryzysów bankowych. Niemniej w przeszłości po ukształtowaniu się współczesnej gospodarki światowej problem niewypłacalności państw dotyczył głównie tych z grupy rozwijających się. Obecnie sytuacja uległa zasadniczej zmianie. Dłużnikami z problemami ze spłatą zaciągniętych zobowiązań stały się państwa rozwinięte, które stanowią zasadniczy filar obowiązującego ładu gospodarczego i politycznego. Do grupy tej należą także państwa Europy Zachodniej wchodzące w skład Unii Gospodarczej i Walutowej. Tym samym uzasadniona wydaje się obawa o przyszłość strefy euro w warunkach bankructwa poszczególnych jej członków, jak również perspektywy innych tego typu przedsięwzięć walutowych.

${ }^{4}$ Por. ibidem, tabela 6.1, s. 87. 


\section{Kryzys finansowy $2007+$ a problem długu publicznego w strefie euro}

Dług publiczny oraz problemy $\mathrm{z}$ utrzymaniem równowagi wewnętrznej i zewnętrznej występowały w państwach Unii Europejskiej czy strefy euro, jak również w innych regionach już w przeszłości. Dane zawarte w tabeli 3 wskazują, że stopniowe przyspieszenie wzrostu zadłużenia w skali globalnej rozpoczęło się w 2003 roku. Jeszcze w 2002 roku łączny dług na świecie osiągnął wartość 18949 bln dol., natomiast już rok później wynosił 21780 bln dol. W 2011 roku łączny dług publiczny w skali całej współczesnej gospodarki światowej osiągnął wartość 41919 bln dol.

Tabela 3. Dług publiczny na świecie w latach 2000-2011 (w bln dol.)

\begin{tabular}{|l|c|l|c|}
\hline Rok & Wartość długu & Rok & Wartość długu \\
\hline 2000 & 18875 & 2006 & 26919 \\
\hline 2001 & 18256 & 2007 & 28797 \\
\hline 2002 & 18949 & 2008 & 31515 \\
\hline 2003 & 21780 & 2009 & 35202 \\
\hline 2004 & 25149 & 2010 & 39321 \\
\hline 2005 & 26773 & 2011 & 41919 \\
\hline
\end{tabular}

Źródło: T. Gruszecki, op.cit., s. 14.

Powyższą prawidłowość, a więc względne ustabilizowanie sytuacji w sferze finansów publicznych w latach 90. XX wieku i na początku wieku XXI potwierdzają również dane zawarte w tabeli 4 odnoszące się do poszczególnych państw strefy euro. W wielu państwach strefy euro dług przekraczał przyjęte dopuszczalne limity, nie obserwowano jednak znaczących skokowych zmian wskazujących na pogorszenie kondycji finansów publicznych. Nie sugerowały tego także oceny wiarygodności papierów dłużnych emitowanych przez państwa członkowskie. Tym bardziej że jeszcze w 2007 roku udało się obniżyć poziom długu publicznego w strefie euro do najniższego poziomu od jej powstania. Także w ramach Unii Europejskiej liczącej 27 państw średni dług publiczny osiągnął w tym roku wartość 59,0\% PKB. 


\begin{tabular}{|c|c|c|c|c|c|c|c|c|c|c|c|c|c|c|c|c|c|c|c|}
\hline & $\overrightarrow{\vec{\Delta}}$ & $\left|\begin{array}{l}0 \\
\hat{\alpha} \\
\infty\end{array}\right|$ & $\hat{\infty}$ & & 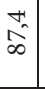 & ב̂. & : & $=0$ & $=\left[\begin{array}{l}\infty \\
\infty \\
\infty\end{array}\right.$ & $b_{0}^{2}$ & $\begin{array}{l}n^{2} \\
08 \\
0\end{array}$ & & 党 & $\begin{array}{l}c \\
c \\
c\end{array}$ & & $\stackrel{\infty}{0}_{0}^{\infty}$ & $\overbrace{}^{2}$ & 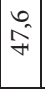 & $\overrightarrow{\hat{\Xi}}$ \\
\hline & 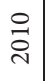 & $\left|\begin{array}{c}0 \\
0 \\
0 \\
0\end{array}\right|$ & $\begin{array}{l}\hat{8} \\
\dot{\infty}\end{array}$ & $\begin{array}{l}2 \\
\infty \\
\infty \\
\infty\end{array}$ & 莡 & $\vec{\Sigma}$ & 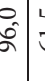 & $=$ & $\hat{b}$ & 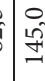 & $\frac{1}{6}$ & त्रे & $\begin{array}{l}n \\
\hat{\alpha} \\
\hat{\alpha}\end{array}$ & क. & $\begin{array}{l}* \\
0\end{array}$ & $\stackrel{m}{\alpha}$ & & $\left|\begin{array}{l}\infty \\
0 \\
\infty \\
\infty \\
\infty\end{array}\right|$ & 吕 \\
\hline & ذ્ণે & $\mid \begin{array}{l}\infty \\
+ \\
i\end{array}$ & $\mid \begin{array}{l}n \\
n \\
1\end{array}$ & $\hat{\imath}$ & $\begin{array}{l}0 \\
\stackrel{0}{0}\end{array}$ & की & 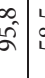 & רeln & 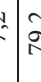 & İ & ले & $\begin{array}{l}\infty \\
0 \\
0\end{array}$ & $\overrightarrow{60}$ & . & & $\vec{\infty}$ & $\begin{array}{c}0 \\
0 \\
0 \\
m\end{array}$ & {$\left[\begin{array}{c}m \\
\omega^{2} \\
m\end{array}\right.$} & $\begin{array}{l}0 \\
\hat{\theta} \\
= \\
=\end{array}$ \\
\hline & 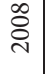 & $\mid$ & గ̂. & $\vec{\imath}$ & $\stackrel{2}{2}$ & 今̂ & $a_{\infty}^{2}$ & की & $f \infty$ & $\stackrel{m}{=}$ & 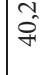 & $\left|\begin{array}{l}n \\
0 \\
0 \\
0 \\
n \\
n\end{array}\right|$ & f & $\hat{\imath}$ & $\begin{array}{c}0 \\
0\end{array}$ & $\overbrace{i}^{0}$ & $\begin{array}{l}\hat{i} \\
\hat{\lambda}\end{array}$ & $\overrightarrow{\vec{v}}$ & 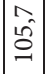 \\
\hline & ڤ్̀े & 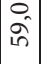 & {$\left[\begin{array}{l}0 \\
\text { in }\end{array}\right.$} & & 包 & : & $\overrightarrow{+5}$ & - & 8 & 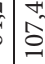 & 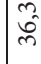 & $\mid \begin{array}{c}2 \\
2^{2}\end{array}$ & 冓 & $\hat{\sigma}$ & $\begin{array}{c}0 \\
\hat{\sigma} \\
0\end{array}$ & $\hat{\alpha}_{0}^{2}$ & î. & $\overrightarrow{\hat{\imath}}$ & $\overrightarrow{\widehat{\rho}}$ \\
\hline & 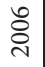 & $\mid \begin{array}{l}0 \\
0 \\
0\end{array}$ & $\overrightarrow{\hat{\delta}}$ & 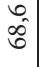 & बी & 苞 & s. & $8=$ & $\tilde{\sigma}$ & 8 & के & $\mid \begin{array}{c}\vec{⿱} \\
\vec{\gamma}\end{array}$ & 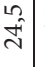 & tô & & $\hat{\theta}^{2}$ & $\left|\begin{array}{l}n_{0} \\
\bar{n}\end{array}\right|$ & $\mid$ & $\overrightarrow{0}$ \\
\hline & 岕 & $\widehat{\hat{S}}$ & $\left(\begin{array}{l}2 \\
\hat{6}\end{array}\right.$ & है & $\stackrel{m}{R}$ & से & बू. & 6 & $f$ & 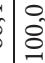 & 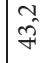 & $\left|\begin{array}{l}\infty \\
\vec{n} \\
\hat{n}\end{array}\right|$ & $\stackrel{2}{3}$ & $\overrightarrow{6}$ & $\sigma^{\circ}$ & $\stackrel{\hat{0}}{\hat{\sigma}}$ & 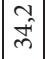 & | & 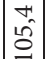 \\
\hline & $\begin{array}{l}\text { ते } \\
\text { ते }\end{array}$ & {$\left[\begin{array}{l}n \\
\hat{S}\end{array}\right]$} & $\mid \begin{array}{l}0 \\
\hat{i} \\
0\end{array}$ & 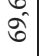 & $\hat{\mathrm{o}}$ & से & से & Q & $b_{0}^{\circ}$ & {$\left[\begin{array}{ll}0 \\
\infty^{\circ}\end{array}\right.$} & کో & $\mid \begin{array}{r}\vec{j} \\
\hat{n}\end{array}$ & 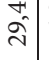 & की & $=\hat{F}$ & $\vec{b}$ & $\mid \begin{array}{l}n \\
7 \\
7\end{array}$ & $\stackrel{2}{2}$ & 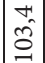 \\
\hline $\begin{array}{l}\stackrel{2}{a} \\
\therefore \\
0\end{array}$ & ڤ̊̀े & $\overrightarrow{\hat{b}}$ & $\mid \begin{array}{l}\hat{\sigma} \\
\hat{S}\end{array}$ & ถి & ถి & فी & $\begin{array}{lll}1 \\
\alpha\end{array}$ & $\hat{b}^{\prime}$ & $\hat{i}$ & $\hat{~}$ & $\mid \begin{array}{l}\infty \\
\infty \\
\infty \\
\alpha\end{array}$ & $\left|\begin{array}{c}0 \\
\hat{i n}\end{array}\right|$ & $\begin{array}{l}\hat{\mathrm{\rho}} \\
\mathrm{o}\end{array}$ & $\overrightarrow{\sigma^{0}}$ & & مै & $\mid \begin{array}{l}\vec{\gamma} \\
\hat{f}\end{array}$ & $\mid \begin{array}{c}2 \\
\\
\end{array}$ & $\hat{\hat{\Omega}}$ \\
\hline 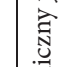 & ڤ్ ڤે & $\mid$ & 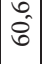 & 它 & $\overrightarrow{\hat{\theta}}$ & : & 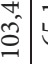 & 60 & $\hat{s}=0$ & $\underline{3}$ & $\mid \begin{array}{l}0 \\
i \\
i n\end{array}$ & $\left|\begin{array}{l}n \\
0 \\
10\end{array}\right|$ & $\vec{m}$ & की & مी & $\begin{array}{l}6 \\
0 \\
0^{\circ}\end{array}$ & $\mid \begin{array}{l}+ \\
\mathfrak{f}^{\prime}\end{array}$ & $\mid \begin{array}{l}\infty \\
\hat{N} \\
\hat{n}\end{array}$ & $\overrightarrow{\hat{\theta}}$ \\
\hline $\begin{array}{l}200 \\
\frac{010}{2}\end{array}$ & 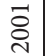 & $|0|$ & {$\left[\begin{array}{l}7 \\
6 \\
6\end{array}\right.$} & {$\left[\begin{array}{c}\mathcal{2} \\
0 \\
0 \\
0\end{array}\right]$} & 趈 & : & 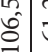 & $\frac{\pi}{6}=$ & 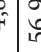 & $\hat{s}$ & $\mid \begin{array}{l}6 \\
\text { กิ }\end{array}$ & î́. & 今̂ & 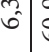 & है & 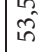 & $\mid \begin{array}{c}\hat{\alpha} \\
\text { âd }\end{array}$ & & 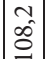 \\
\hline & ¿े & $\hat{\vec{b}}$ & $\overrightarrow{\hat{\delta}}$ & {$\left[\begin{array}{c}2 \\
0 \\
0\end{array}\right.$} & శ్ర & : & $\begin{array}{l}\infty \\
0 \\
0\end{array}$ & $\begin{array}{ll}0 \\
\vdots \\
10\end{array}$ & $\hat{n}$ & 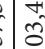 & 吾 & $\mid \begin{array}{l}\infty \\
\hat{1}\end{array}$ & 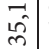 & ช્| & for & 㤩 & $\hat{c}^{2}$ & 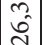 & {$\left[\begin{array}{ll}12 \\
0 \\
0\end{array}\right.$} \\
\hline & 2 & {$\left[\begin{array}{l}\infty \\
5 \\
10\end{array}\right.$} & की & {$\left[\begin{array}{l}0 \\
-1\end{array}\right.$} & $\hat{\approx}$ & $\begin{array}{l}\infty \\
0 \\
0 \\
0\end{array}$ & $\begin{array}{l}0 \\
\tilde{c}^{2}\end{array}$ & $\sigma^{2}=$ & $\hat{o}^{2}$ & 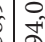 & $\stackrel{+}{s}$ & $\Rightarrow$ & $\begin{array}{l}0 \\
0\end{array}$ & $\begin{array}{l}t^{\prime} \\
6\end{array}$ & $\Rightarrow=$ & $\stackrel{+}{\Rightarrow}$ & $\stackrel{\infty}{\wedge}$ & $\overrightarrow{f f}$ & $\stackrel{0}{m}$ \\
\hline & & & & $\sqrt{2}$ & 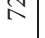 & 6 & $\exists$ & in 4 & o i & i & & 6 & & 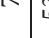 & & $\bar{n}$ & & & $\underset{\Xi}{\exists}$ \\
\hline & ڤे & {$\left[\begin{array}{l}2 \\
0 \\
0 \\
0\end{array}\right]$} & $\mid \begin{array}{l}\vec{b} \\
0 \\
0\end{array}$ & {$\left[\begin{array}{c}n \\
n\end{array}\right]$} & న్ & $\overrightarrow{\mathbb{b}^{2}}$ & 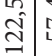 & in & $=0$ i & 10 & $\overline{8}$ & 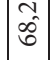 & $\overrightarrow{\hat{6}}$ & $\stackrel{*}{\cong}$ & 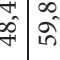 & $\begin{array}{l}\text { 令 } \\
\text { in }\end{array}$ & लि & $\overrightarrow{\hat{i}} \mid$ & $\stackrel{+}{\stackrel{H}{\Xi}}$ \\
\hline & ڤ̊ & हे & 疍 & م̂n. & $\hat{\wedge}$ & ही & $\underset{\simeq}{\tilde{\Xi}}$ & $\overrightarrow{\hat{n}}$ & $\begin{array}{l}0 \\
0\end{array}$ & $\hat{\alpha}$ & 芯 & $\vec{f}$ & $\hat{\imath}$ & $\stackrel{*}{\therefore}$ & 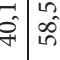 & $\mid \begin{array}{l}\infty \\
\infty \\
n \\
n\end{array}$ & $\vec{m}$ & $\overrightarrow{\vec{N}}$ & 今̂ \\
\hline & 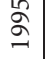 & I & $\mid$ & $\mid$ & în & 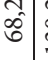 & 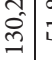 & $\stackrel{\infty}{=\infty}$ & $\begin{array}{l}y \\
0 \\
0\end{array}$ & 令 & స్ & $\overrightarrow{0}$ & 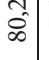 & $\stackrel{+}{\therefore}$ & & مू & $\mid \overrightarrow{\mathfrak{i}}$ & {$\left[\begin{array}{c}0 \\
\infty^{0}\end{array}\right.$} & $\begin{array}{l}\hat{\Xi} \\
\hat{\Xi}\end{array}$ \\
\hline & & 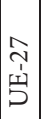 & & 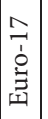 & 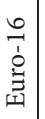 & : & 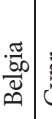 & 密 & $\begin{array}{l}0 \\
0\end{array}$ & كֶّ & & 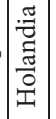 & . & 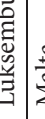 & & 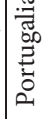 & 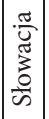 & & $\begin{array}{l}\overrightarrow{\hat{\theta}} \\
\overrightarrow{0} \\
\overrightarrow{3} \\
\overrightarrow{3}\end{array}$ \\
\hline
\end{tabular}




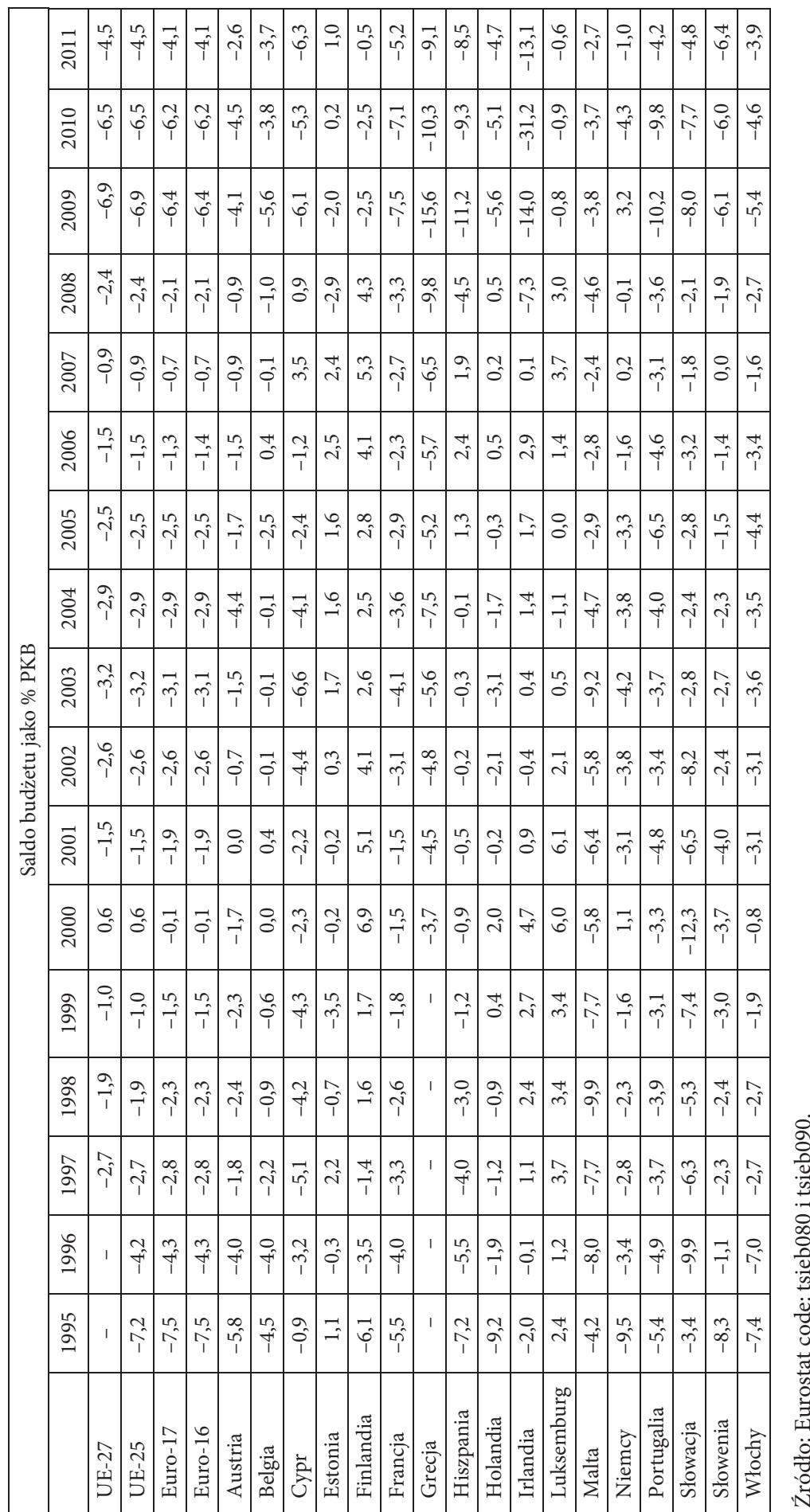


Względnie stabilną i jak mogłoby się wydawać dobrą sytuację w strefie euro potwierdzały zarówno oceny rynków walutowych i umacnianie się wspólnej waluty regionalnej - euro względem dolara amerykańskiego i innych walut istotnych dla rozliczeń międzynarodowych, jak również rosnąca popularność euro jako waluty rezerwowej i rozliczeniowej w transakcjach handlu międzynarodowego. Ponadto państwa należące do unii walutowej osiągały korzyść poprzez możliwość taniego pozyskiwania na rynkach międzynarodowych środków na finansowanie nierównowagi finansów publicznych, także tej o pierwotnym charakterze. Można domniemywać, że uwarunkowania te nieco uśpiły czujność zarówno samych państw członkowskich, jak i instytucji unijnych czy podmioty zewnętrzne. Tym bardziej że pewne niepokojące sygnały co do spójności polityki gospodarczej i stabilności finansów publicznych, które miały być podstawą tworzenia konkurencyjnej gospodarki w skali globalnej wspierającej wzrost i zatrudnienie, były widoczne już w owym okresie. Oczekiwana dynamika wzrostu PKB w strefie euro odbiegała od oczekiwań - przykładowo średni wzrost realnego PKB w strefie euro w 2002 roku osiągnął zaledwie $0,9 \%$, a rok później $0,7 \% j^{5}$.

Bardzo często wskazuje się, że zaistniała sytuacja spowodowała, iż w 2005 roku zdecydowano się na pierwszą modyfikację Paktu Stabilności i Wzrostu ${ }^{6}$ a w dniu 20 marca 2005 roku na nadzwyczajnym posiedzeniu Rady ECOFIN przyjęte zostało sprawozdanie zatytułowane „Poprawa wdrażania Paktu na rzecz Stabilności i Wzrostu"'. Celem oficjalnie wskazanym w dokumentach było wzmocnienie zarządzania i krajowej odpowiedzialności za ramy fiskalne poprzez umocnienie fundamentów ekonomicznych i skuteczności paktu zarówno w sferze prewencyjnej, jak i korygującej. Ponadto zdecydowano się skoncentrować na zabezpieczeniu stabilności finansów publicznych w długim okresie, wspieraniu wzrostu i unikaniu nakładania nadmiernych obciążeń na przyszłe pokolenia. W sprawozdaniu potwierdzono także, że pakt będzie stanowił zasadniczy element makroekonomicznych ram Unii Gospodarczej i Walutowej, gdyż poprzez inicjatywy na rzecz koordynacji narodowej polityki budżetowej i unikania nadmiernych deficytów będzie przyczyniał się do osiągania stabilności makroekonomicznej w UE. Wskazywano również, że będzie odgrywał kluczową rolę w zapewnieniu niskiej inflacji i niskich stóp procentowych, które to w zasadniczy sposób miały przyczyniać się do osiągania zrównoważonego wzrostu

5 Eurostat code: tec00115.

6 Rozporządzenie (WE) nr 1055/2005 z dnia 27 czerwca 2005 r. zmieniające rozporządzenie (WE) nr 1466/97 w sprawie wzmocnienia nadzoru pozycji budżetowych oraz nadzoru i koordynacji polityk gospodarczych oraz rozporządzenie (WE) nr 1056/2005 z dnia 27 czerwca 2005 r. zmieniające rozporządzenie Rady (WE) nr 1467/97 w sprawie przyspieszenia i wyjaśnienia procedury nadmiernego deficytu.

7 Sprawozdanie Rady nr 7423/5/05 z 26 maja 2005 r. 
gospodarczego i tworzenia miejsc pracy ${ }^{8}$. Niemniej jednak w dokumencie tym wskazano na pewne mankamenty i wątpliwości. Początkowo stwierdzono, że o ile przyjęte zasady i kryteria nadzoru w sferze finansów publicznych są słuszne, o tyle pewne wątpliwości i niepokój wzbudzają sposoby egzekwowania poszczególnych zapisów. Dlatego uznano za niezbędne zwiększenie przejrzystości regulacji i stosowanych rozwiązań, jak również krajowego zaangażowania i rzetelności w realizacji ram fiskalnych. Za niezbędne uznano także pełną i terminową komunikację między poszczególnymi instytucjami oraz pomiędzy instytucjami a opinią publiczną. W sprawozdaniu argumentowano w związku z tym, że reforma paktu ma na celu lepszą reakcję na odczuwane dotychczas braki poprzez położenie większego nacisku na sprawy gospodarcze i wzmożoną koncentrację na zabezpieczeniu równowagi finansów publicznych. Niestety, bardziej dogłębna analiza dwóch rozporządzeń modyfikujących pakt pokazuje, że była to tylko propagandowa misterna gra słów o politycznym charakterze. W praktyce wprowadzone zmiany należy ocenić jako próbę zluzowania i zliberalizowania wcześniejszych postanowień i zobowiązań. Modyfikacja polegała bowiem na złagodzeniu wcześniejszych zapisów i zwiększeniu elastyczności podejmowanych decyzji, a także ograniczeniu egzekwowania potencjalnych sankcji nakładanych na państwa niewywiązujące się z zaleceń i niezwalczające skutecznie nadmiernego deficytu, który pogłębiał skalę zadłużenia publicznego. W nowych regulacjach uwzględniona została bowiem zasada, że Pakt Stabilności i Wzrostu nie ma mieć charakteru restrykcyjnego oraz nie powinien ograniczać się do nakładania kar i sankcji, lecz przede wszystkim powinien skoncentrować się na koordynacji działań i wsparciu państw znajdujących się w kłopotach. Wprowadzone zmiany wynikały w dużej mierze z faktu, iż coraz liczniejsza grupa państw miała problemy z utrzymaniem dyscypliny finansowej. Ewentualne restrykcje, które powinny zostać nałożone zgodnie z wcześniejszymi zapisami, nie byłyby dobrze odebrane przez obywateli i wyborców w tych państwach. Tym bardziej że do grona państw zagrożonych zaliczały się nie tylko państwa średnie lub małe, lecz także Niemcy czy Francja.

Istotna zmiana rozumiana jako pogorszenie sytuacji w sferze finansów publicznych zbiegła się z kryzysem finansowym, który następnie przekształcił się w kryzys gospodarczy, a ostatecznie zadłużeniowy. W celu łagodzenia skutków światowego kryzysu państwo i jego instytucje ponownie musiały się uaktywnić. Rządy większości państw podjęly działania z zakresu polityki fiskalnej, stanowiące element większych pakietów antykryzysowych. Działania fiskalne były uzupełniane przez interwencje oraz różne instrumenty stosowane przez banki centralne. Skala ekspansji fiskalnej, rozumianej jako obniżenie podatków lub zwiększenie wydatków budżetowych,

\footnotetext{
8 Ibidem, s. 2.
} 
miała charakter bezprecedensowy. Tylko w ciągu pierwszych kilku miesięcy kryzysu członkowie G-20 przyjęli pakiety fiskalne o wartości blisko 2 bln dol. Zdecydowana większość tej kwoty została przeznaczona na dokapitalizowanie sektora bankowego w celu podniesienia płynności finansowej oraz przywrócenia akcji kredytowej. Niestety, tylko niewielka część wydatków związana była z tworzeniem nowych miejsc pracy oraz utrzymaniem już istniejących, co negatywnie odbiło się na rynkach pracy.

Działania pomocowe zarówno dla sektora finansowego, jak i realnej sfery gospodarki podejmowane były także przez państwa członkowskie Unii Europejskiej, w tym także strefy euro. Do czerwca 2009 roku żadnych działań o charakterze pomocy publicznej w odniesieniu do sektora finansowego Unii Europejskiej nie podjęło jedynie osiem państw członkowskich. W przypadku niektórych z nich wynikało to z bardzo trudnej sytuacji w sektorze finansów publicznych i jednoczesnych zobowiązań w sferze polityki kursu walutowego. Łączna pomoc publiczna w Unii Europejskiej zatwierdzona przez Komisję Europejską i skierowana tylko do sektora finansowego do połowy 2009 roku wyniosła 3319,7 mld euro. Największe programy gwarancji w ujęciu bezwzględnym wdrożyły Dania, Niemcy, Irlandia, Wielka Brytania i Francja - powyżej 250 mld euro. W ramach Unii Europejskiej przyjęty został także jesienią 2008 roku Europejski Plan Naprawy Gospodarczej, który przewidywał przeznaczenie na różne projekty rozwojowe kwotę 200 mld euro $^{10}$. Ponadto poszczególne państwa członkowskie realizowały własne programy ożywiania gospodarki.

$\mathrm{W}$ pomoc gospodarce i instytucjom rynku finansowego obok rządów zaangażowały się także banki centralne. W obliczu gwałtownego załamania podaży kapitału banki centralne, w tym Europejski Bank Centralny, stanęły wobec konieczności zapewnienia płynności w sektorze bankowym oraz zwiększonej dbałości o wzrost gospodarczy ${ }^{11}$. Ponadto aktywnie angażowały się i nadal to czynią na rynku długu. Przykładowo Europejski Bank Centralny nie może oficjalnie nabywać na rynku pierwotnym papierów dłużnych emitowanych przez państwa członkowskie. Czyni to jednak pośrednio, uruchamiając niestandardowe instrumenty i angażując się na rynku wtórnym. Ponadto EBC, podobnie jak FED, uruchomił wiele niestandardowych instrumentów, które w sytuacji niewielkiej efektywności oddziaływania podstawowych stóp procentowych miały wpływać na poprawę i stabilizację sytuacji w europejskim systemie finansowym, a szczególnie w strefie euro.

9 Państwa, które do 19 czerwca 2008 roku nie podjęły żadnych działań w formie pomocy publicznej dla sektora finansowego, to: Bułgaria, Cypr, Czechy, Estonia, Litwa, Malta, Rumunia i Słowacja.

10 Por. N. Roubini, S. Mihm, Ekonomia kryzysu, Oficyna Wolters Kluwer Business, Warszawa 2011, s. 192.

11 O skali problemów wynikających z zamrożenia rynku międzybankowego może świadczyć fakt, że już 9 sierpnia 2007 roku Europejski Bank Centralny pożyczył 94 mld euro około pięćdziesięciu bankom, następnego dnia udzielił podobnej pomocy na kwotę 61 mld euro. Także System Rezerwy Federalnej udzielił analogicznej pomocy na kwotę 60 mld dol. w ciągu dwóch dni. Por. ibidem, s. 123. 
W krótkim okresie podejmowane przez banki centralne działania były konieczne dla podtrzymania płynności w systemach finansowych i przeciwdziałania gwałtownemu załamaniu produkcji, handlu i inwestycji. Niemniej jednak należy podkreślić, że reakcja na kryzys przybrała postać działań, które wcześniej w dużej mierze doprowadziły do jego wygenerowania. Sprowadzały się one bowiem do wpompowania płynności do systemu finansowego i obniżenia stóp procentowych w skali całego międzynarodowego systemu finansowego.

Uruchamiane w różnej postaci pakiety pomocowe dla realnej sfery gospodarki i pomoc dla sektora finansowego w państwach Unii Europejskiej i strefie euro oznaczały bardzo często upaństwowienie części długu prywatnego. Tym samym w sposób istotny i co szczególnie ważne długotrwały zaowocowało to znaczącym pogorszeniem się wskaźników długu publicznego. Analizując bowiem skalę zadłużenia gospodarek, najczęściej koncentrujemy się na jednym z elementów - długu publicznym, marginalizując znaczenie długu prywatnego. Tymczasem ten drugi w całej swojej masie bardzo często znacznie przewyższa zobowiązania zaciągnięte przez państwo. Sytuacja taka występuje w wielu państwach Unii Europejskiej, w tym także strefy euro (rysunek 1).

Rysunek 1. Stan zadłużenia poszczególnych gospodarek bez uwzględnienia wartości aktywów i zdolności podmiotów do spłaty zadłużenia (w \% PKB, średnia w latach 2008-2010)

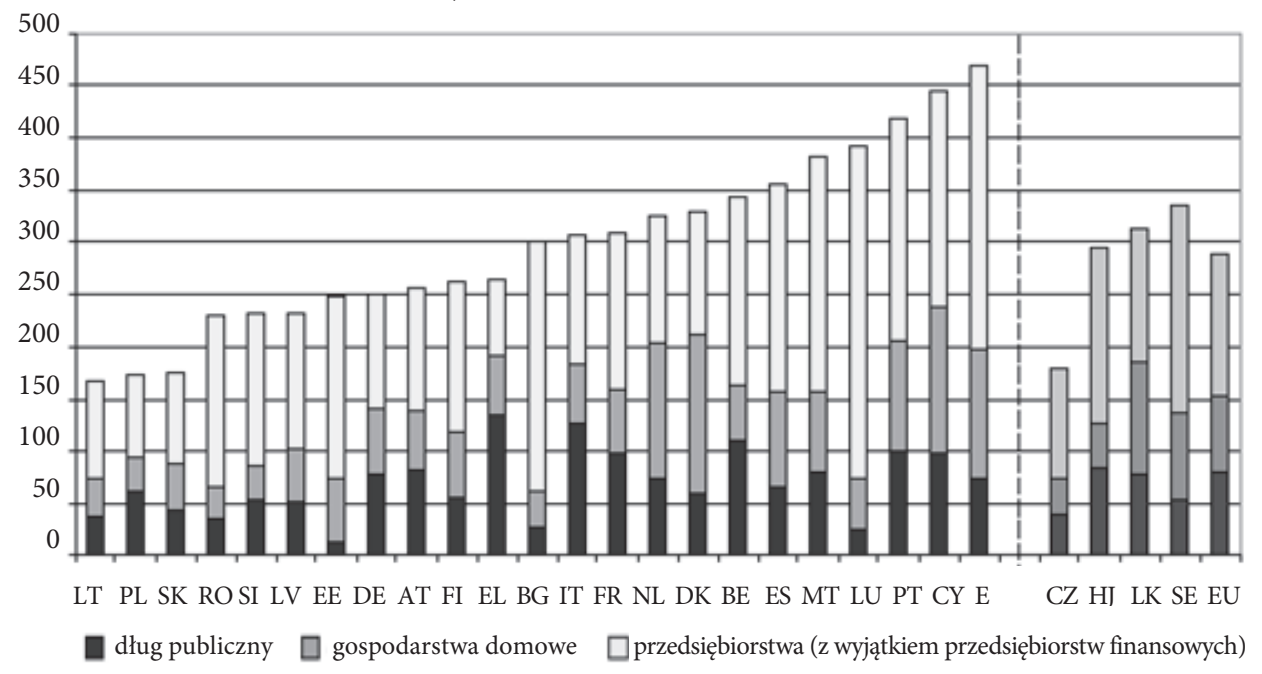

Źródło: Prezentacja J.M. Barroso na posiedzeniu Rady Europejskiej w dniu 9 grudnia 2011 roku.

Należy jednak zauważyć, że rysunek 1 nie prezentuje w pełni sytuacji w sferze łącznego długu poszczególnych państw, nie uwzględnia bowiem zadłużenia 
przedsiębiorstw finansowych. A sektor ten należy do najbardziej zadłużonych. Problemem jest także to, że skala tego zadłużenia nie jest jeszcze w pełni znana, co potwierdzają co chwila pojawiające się problemy instytucji finansowych. Hiszpania i pomoc dla jej sektora finansowego rzędu 100 mld euro - próbowano pozyskać nawet 300 mld euro - nie jest wyjątkiem w tej kwestii. Jeśli, jak wskazuje P. De Grauwe, gdy dług publiczny w strefie euro spadł z prawie 72\% PKB w 1999 roku do około 67\% PKB w 2007 roku, to w tym samym czasie dług gospodarstw domowych wzrósł z 52\% PKB do 70\% PKB. Jednocześnie dług instytucji finansowych wzrósł z mniej niż $200 \%$ PKB do ponad 250\% PKB. Tak więc wzrost długu publicznego po 2007 roku był w przypadku wielu państw bezpośrednim następstwem prowadzonych akcji ratunkowych sektora prywatnego, a zwłaszcza finansowego ${ }^{12}$. Z sytuacją taką mamy do czynienia m.in. w Hiszpanii i Irlandii, a także Portugalii, które dla utrzymania wypłacalności zmuszone zostały skorzystać z pomocy z Unii Europejskiej. Hiszpania i Irlandia prowadziły względnie oszczędną politykę budżetową, co umożliwiło w sposób istotny zredukować dług publiczny - w Hiszpanii z 67,4\% PKB w 1996 roku do 36,3\% PKB w 2007 roku, natomiast w Irlandii z 71,7\% PKB w 1996 roku do $24,8 \%$ PKB w 2007 roku. Sukcesy na tym polu zostały w dużej mierze zaprzepaszczone przez wzrost zadłużenia prywatnego i akcję upaństwowienia części tego długu. W 2011 roku dług publiczny w Hiszpanii wzrósł do 68,5\% PKB, mimo radykalnych cięć w wydatkach budżetowych, natomiast w przypadku Irlandii kształtował się on na poziomie $108,2 \% \mathrm{PKB}^{13}$.

Reasumując, zmiany, jakie zaszły na przestrzeni ostatnich lat i jakie zachodzą obecnie w sferze długu publicznego, a także prywatnego, wskazują, że problemem nie jest fakt istnienia nadmiernego zadłużenia i ewentualnej niewypłacalności poszczególnych państw, lecz skala długu, z jaką stykamy się obecnie, oraz zmiana struktury podmiotowej dłużników i samego długu.

\section{Próby rozwiązania kryzysu zadłużeniowego i utrzymania strefy euro}

Nowe uwarunkowania ukazujące słabość niektórych gospodarek i ich struktur finansowych zaowocowały nie tylko obawami co do wypłacalności niektórych z nich, lecz także co do perspektyw utrzymania przedsięwzięcia walutowego, jakim jest strefa

12 Por. T. Gruszecki, op.cit, s. 75 oraz P. De Grauwe, Fighting the Wrong Enemy, VOX Reaserch-based Policy Analysis, www.voexu.org

13 Eurostat code: tsieb090. 
euro. Tworząc Unię Gospodarczą i Walutową, nie przewidziano bowiem wystarczających mechanizmów pomocowych w sytuacji poważnych problemów finansowych i gospodarczych państw członkowskich. Szczególnie uwidoczniło się to po załamaniu gospodarczym 2007+. Jako pierwsza poważne trudności zaczęła przeżywać Grecja, a w jej ślady poszły gospodarki Irlandii i Portugalii. Obecnie zagrożenie dotyczy Hiszpanii, Włoch oraz Belgii. W odpowiedzi na zaistniałą sytuację państwa członkowskie podjęły w pierwszej kolejności tymczasowe działania, a następnie przystąpiły do tworzenia stałych mechanizmów stabilizacyjnych.

Działania tymczasowe, które miały obowiązywać do wprowadzenia bardziej trwałych rozwiązań, sprowadzały się do ustanowienia Europejskiego Mechanizmu Stabilizacji Finansowej i Europejskiego Instrumentu Stabilności Finansowej funkcjonującego poprzez Europejski Fundusz Stabilności Finansowej. Europejski Mechanizm Stabilizacji Finansowej został powołany do życia na mocy rozporządzenia Rady (UE) nr 407/2010 z dnia 11 maja 2010 r. ${ }^{14}$ Uzyskał on pełną gwarancję budżetu UE. W art. 1 ustalono, że dla zachowania stabilności finansowej Unii Europejskiej pomoc finansowa Unii może zostać przyznana państwu członkowskiemu, które ma poważne trudności gospodarcze lub finansowe lub też jest nimi istotnie zagrożone z racji nadzwyczajnych okoliczności pozostających poza jego kontrolą. Utrzymano również możliwość zastosowania obowiązującego instrumentu średnioterminowej pomocy finansowej dla bilansów płatniczych państw członkowskich nienależących do strefy euro, ustanowionego rozporządzeniem (WE) nr 332/2002. Natomiast Europejski Instrument Stabilności Finansowej (Europejski Fundusz Stabilności Finansowej) został utworzony w czerwcu 2010 roku przez państwa członkowskie strefy euro jako spółka będąca ich własnością z siedzibą w Luksemburgu, zgodnie z decyzjami podjętymi dnia 9 maja 2010 roku w ramach Rady ECOFIN. Europejski Fundusz Stabilności Finansowej może emitować obligacje o łącznej wartości do 440 mld euro gwarantowane przez państwa członkowskie strefy euro ${ }^{15}$, przy czym środki pozyskiwane $\mathrm{z}$ emisji tych obligacji są następnie udostępniane $\mathrm{w}$ formie pożyczek państwom członkowskim strefy euro znajdującym się w trudnej sytuacji, na warunkach wynegocjowanych z Komisją Europejską działającą w porozumieniu z Europejskim Bankiem Centralnym i Międzynarodowym Funduszem Walutowym oraz zatwierdzonych przez Eurogrupę.

14 Odwołano się w nim do art. 122 ust. 2 Traktatu o funkcjonowaniu Unii Europejskiej, przewidującego możliwość przyznawania pomocy finansowej państwom członkowskim, które znalazły się w trudnej sytuacji z racji nadzwyczajnych okoliczności pozostających poza ich kontrolą.

15 Po zmianach zakończonych ratyfikacją w październiku 2011 roku poziom ten zwiększył się do 780 mld euro, a poziom pożyczek zwiększył się z 250 mld do 440 mld euro. 
Okazało się jednak, że inicjatywy te nie były wystarczające. Rozmowy w sprawie utworzenia stałych mechanizmów uruchamianych w warunkach kryzysowych prowadzone były od dawna. Dopiero na posiedzeniu Rady Europejskiej w dniach 28-29 października 2010 roku szefowie państw i rządów zgodzili się, że państwa członkowskie powinny ustanowić stały mechanizm kryzysowy służący ochronie stabilności finansowej strefy euro jako całości. Ministrowie Eurogrupy uzgodnili także, że będzie on opierał się na Europejskim Instrumencie Stabilności Finansowej (Europejskim Funduszu Stabilności Finansowej) i będzie mógł zapewniać pakiety pomocy finansowej państwom członkowskim strefy euro, z zastrzeżeniem spełnienia pewnych rygorystycznych warunków. Uzgodniono także, że nowy mechanizm będzie stanowił uzupełnienie nowych ram wzmocnionego zarządzania gospodarczego ${ }^{16}$ w celu uzyskania skutecznego i ścisłego nadzoru ekonomicznego, który powinien skupić się na zapobieganiu i znacząco zmniejszyć prawdopodobieństwo wystąpienia kryzysu w przyszłości ${ }^{17}$.

Ostateczna wersja traktatu została podpisana 2 lutego 2012 roku. Porozumienie miało wejść w życie po ratyfikowaniu go przez 17 państw członkowskich strefy euro. Początkowo uznano, że powinno to nastąpić przed 1 czerwca 2013 roku. Jednakże skala problemów zarówno w systemach finansowych państw członkowskich, jak i w sferze finansów publicznych doprowadziła do podjęcia decyzji o przyspieszeniu wejścia w życie traktatu - na lipiec 2012 roku $^{18}$. Ogólnie mechanizm ten ma być uruchamiany za wspólnym porozumieniem ${ }^{19}$, $w$ przypadku gdyby było to niezbędne dla ochrony stabilności finansowej strefy euro jako całości. Europejski Mechanizm Stabilności (EMS) ma przejąć rolę Europejskiego Instrumentu Stabilności Finansowej oraz Europejskiego Mechanizmu Stabilizacji Finansowej przy zapewnianiu zewnętrznej pomocy finansowej państwom członkowskim strefy euro.

Ustalono także, że EMS będzie miał efektywną zdolność udzielania pożyczek w wysokości 500 mld euro ${ }^{20}$. Adekwatność zdolności udzielania pożyczek ma podlegać regularnym przeglądom przynajmniej co pięć lat. Ponadto Europejski Mechanizm Stabilności ma dążyć do uzupełnienia swojej zdolności udzielania pożyczek przez udział MFW w operacjach pomocy finansowej. Zdecydowano również,

16 Tzw. sześciopak, o którym szerzej w dalszej części opracowania.

17 Por. Rada Europejska, 16-17 grudnia 2010 r., Konkluzje, EUCO 30/1/10 REV 1, s. 8-9.

18 Treaty Establishing the European Stability Mechanism, FACTSHEET, 2 February 2012, s. 1.

19 Decyzja podejmowana za wspólnym porozumieniem jest decyzją podejmowaną jednomyślnie przez państwa członkowskie biorące udział w tym głosowaniu, tzn. wstrzymanie się od głosu nie uniemożliwia przyjęcia decyzji.

20 Podczas przechodzenia z Europejskiego Instrumentu Stabilności Finansowej do Europejskiego Mechanizmu Stabilności łączna zdolność udzielania pożyczek ma nie przekroczyć powyższej kwoty. W świetle ostatnich zmian w ramach EFSF wydaje się to mało prawdopodobne. 
że państwa członkowskie spoza strefy euro mogą uczestniczyć w EMS na zasadzie ad hoc ${ }^{21}$. Całkowity kapitał subskrybowany EMS ma wynieść 700 mld euro (tabela 5).

Tabela 5. Udział poszczególnych państw w lącznym kapitale ESM

\begin{tabular}{|l|c|r|}
\hline \multicolumn{1}{|c|}{ Państwo } & Liczba udziatów & Subskrybowany kapitał (w euro) \\
\hline Belgia & 243397 & 24339700000 \\
\hline Niemcy & 1900248 & 190024800000 \\
\hline Estonia & 13020 & 1302000000 \\
\hline Irlandia & 111454 & 11145400000 \\
\hline Grecja & 197169 & 19716900000 \\
\hline Hiszpania & 833259 & 83325900000 \\
\hline Francja & 1427013 & 142701300000 \\
\hline Włochy & 1253959 & 125395900000 \\
\hline Cypr & 13734 & 1373400000 \\
\hline Luksemburg & 17528 & 1752800000 \\
\hline Malta & 5117 & 511700000 \\
\hline Holandia & 400190 & 40019000000 \\
\hline Austria & 194838 & 19483800000 \\
\hline Portugalia & 175644 & 17564400000 \\
\hline Stowenia & 29932 & 2993200000 \\
\hline Słowacja & 57680 & 5768000000 \\
\hline Finlandia & 125818 & 12581800000 \\
\hline Łącznie & 7000000 & 700000000000 \\
\hline
\end{tabular}

Źródło: Traktat o ESM, Aneks II.

Jeśli będzie to niezbędne do ochrony stabilności strefy euro jako całości, Europejski Mechanizm Stabilności będzie, zgodnie ze zmianą art. 136 Traktatu, udzielał pomocy finansowej z zastrzeżeniem rygorystycznych warunków w ramach makroekonomicznego programu dostosowawczego, proporcjonalnie do stopnia zakłócenia równowagi danego państwa członkowskiego. Pomoc będzie zapewniana w formie pożyczek. Jednakże w wyjątkowych wypadkach mechanizm może podejmować interwencje na pierwotnych rynkach długu na podstawie makroekonomicznego programu dostosowawczego.

Równolegle do tworzenia mechanizmów pomocowych próbowano podejmować działania ukierunkowane nie tyle na łagodzenie skutków zjawisk kryzysowych, ile na wzmacnianie podstaw funkcjonowania wspólnej waluty. W dotychczasowych opracowaniach poświęconych poszukiwaniu sposobów wyjścia z kryzysu zadłużeniowego wymienia się kilka, m.in. restrukturyzację długu, niskie stopy procentowe, inflację, ale przede wszystkim dynamizowanie wzrostu gospodarczego. Jeśli bowiem PKB rośnie szybciej niż dług, to oznacza, że nierównowaga fiskalna zmniejsza się,

${ }^{21}$ Por. Rada Europejska, 24-25 marca 2011 r., Konkluzje, EUCO 10/1/11, s. 21. 
a tym samym ograniczane są pożyczkowe potrzeby państwa. Dlatego też w państwach Unii Europejskiej, w tym także strefy euro, można zaobserwować różne inicjatywy ukierunkowane, z jednej strony, na zacieśnianie współpracy w sferze narodowej polityki gospodarczej, a w szczególności polityki budżetowej oraz utworzenia unii bankowej. $Z$ drugiej zaś strony na wspieranie wzrostu gospodarczego, a szerzej rozwoju społeczno-ekonomicznego.

Dokumentem o podstawowym znaczeniu dla konsolidacji fiskalnej opartej na reformach strukturalnych i stymulowaniu wzrostu gospodarczego jest przyjęta w czerwcu 2010 roku „Strategia Europa 2020”, która zastąpiła strategię lizbońską i jej późniejszą modyfikację. W ramach nowej strategii zatwierdzone zostały priorytety dotyczące konsolidacji fiskalnej i reform strukturalnych. Podkreślono priorytetowe znaczenie przywrócenia dobrej sytuacji budżetowej i jej stabilności, zmniejszenia bezrobocia $\mathrm{w}$ drodze reform rynku pracy oraz podjęcia nowych działań służących zwiększeniu wzrostu. Wszystkie państwa członkowskie zostały zobligowane do przekształcenia tych priorytetów w konkretne środki, które miały zostać włączone do ich programów stabilności lub programów konwergencji przewidzianych w Pakcie Stabilności i Wzrostu oraz do ich krajowych programów reform.

Niestety, inicjatywy te okazały się niewystarczające, dlatego też zdecydowano się na zainicjowanie nowych, przykładowo zintensyfikowania działań i realizacji europejskiego semestru, uzdrowienia sektora bankowego, a także wprowadzenia tzw. Paktu euro plus. Ten ostatni zakłada ściślejszą koordynację polityki gospodarczej służącą zwiększeniu konkurencyjności i konwergencji. Pakt został uzgodniony przez szefów państw lub rządów strefy euro, a przystąpiły do niego również Bułgaria, Dania, Litwa, Łotwa, Polska i Rumunia, aby wzmocnić filar gospodarczy unii walutowej, wprowadzić nową jakość do koordynacji polityki gospodarczej, zwiększyć konkurencyjność, a tym samym zwiększyć stopień konwergencji. Pakt ten w głównej mierze dotyczy tych dziedzin, które objęte są kompetencjami krajowymi i mają kluczowe znaczenie dla zwiększania konkurencyjności i unikania szkodliwych zakłóceń równowagi ${ }^{22}$. Przedmiotem uwagi ma być również koordynacja polityki podatkowej. Opodatkowanie bezpośrednie pozostaje w kompetencji krajowej. Pragmatyczna koordynacja polityki podatkowej jest niezbędnym elementem ściślejszej koordynacji polityki gospodarczej w strefie euro w celu wspierania konsolidacji fiskalnej i wzrostu gospodarczego. W tym kontekście państwa członkowskie zobowiązały się do prowadzenia zorganizowanych dyskusji dotyczących kwestii polityki podatkowej, zwłaszcza po to, by zapewnić wymianę sprawdzonych wzorców, kwestii unikania szkodliwych

${ }^{22}$ Konkluzje Rady Europejskiej z 24-25 marca 2011 r., EUCO 10/1/11 REV 1, Załącznik I Pakt euro plus. Ściślejsza koordynacja polityki gospodarczej służąca zwiększeniu konkurencyjności i konwergencji, s. 13. 
praktyk oraz wniosków w zakresie zwalczania oszustw podatkowych i uchylania się od opodatkowania. Określenie wspólnej podstawy opodatkowania osób prawnych mogłoby być jednym z neutralnych pod względem dochodów sposobów zapewniających spójność krajowych systemów podatkowych, z jednoczesnym poszanowaniem krajowych strategii podatkowych, i przyczynić się do stabilności budżetowej oraz konkurencyjności europejskich przedsiębiorstw. Komisja przedstawiła wniosek ustawodawczy w sprawie wspólnej jednolitej podstawy opodatkowania osób prawnych. Wydaje się jednak, że jest to jeszcze odległa przyszłość.

Aby pokazać rzeczywiste zaangażowanie na rzecz zmian i nadać niezbędny polityczny impuls działaniom na rzecz osiągnięcia wspólnych celów, co roku państwa członkowskie uczestniczące w pakcie mają na najwyższym szczeblu uzgadniać zestaw konkretnych działań, które będzie trzeba zrealizować w ciągu dwunastu miesięcy. Każde państwo ma odpowiadać za wybór konkretnych środków politycznych, które będzie trzeba wprowadzić. Stosowne zobowiązania mają zostać również odzwierciedlone w przedkładanych corocznie krajowych programach reform i programach stabilności, które będą oceniane przez Komisję, Radę i Eurogrupę w kontekście europejskiego semestru ${ }^{23}$. Wzajemne relacje między strategią „Europa 2020” a Paktem euro plus przedstawia rysunek 2 .

\section{Rysunek 2. Kontekst Paktu euro plus}

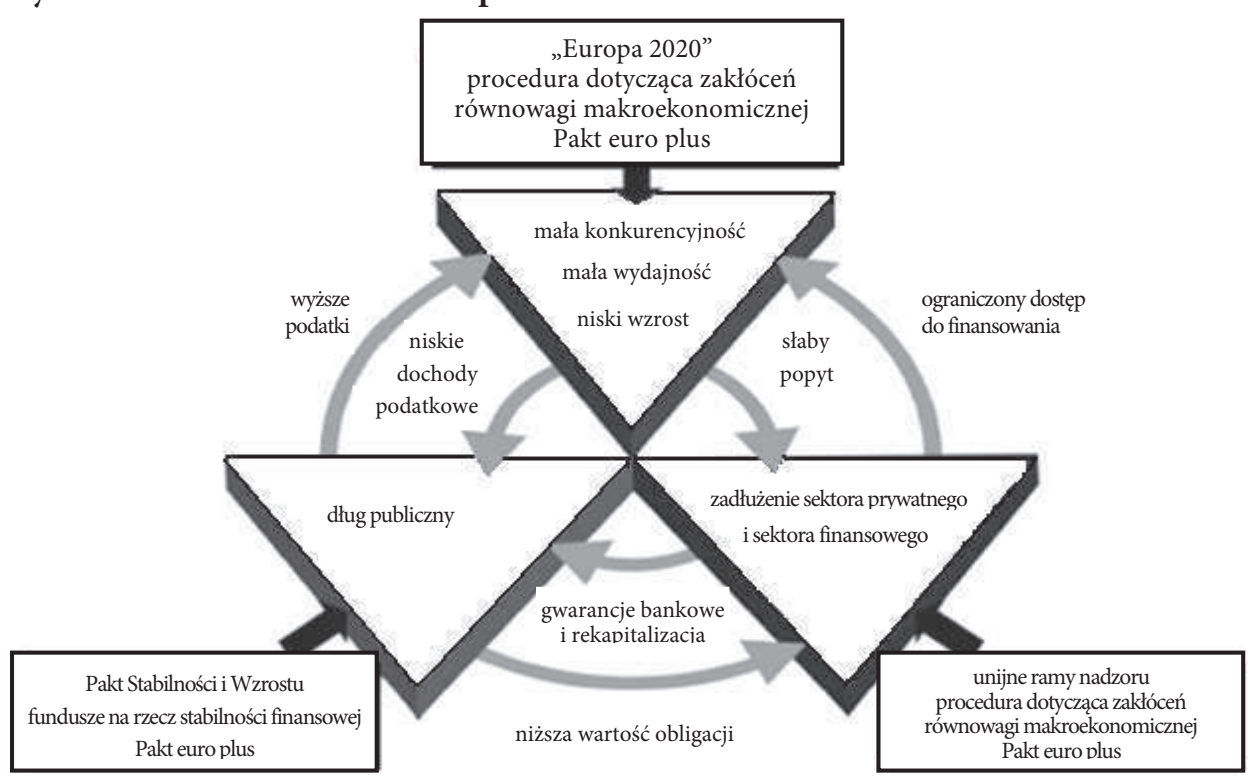

Źródło: Prezentacja J.M. Barroso na posiedzeniu Rady Europejskiej w dniu 9 grudnia 2011 roku.

\footnotetext{
23 Por. ibidem, s. 19-20.
} 
Mimo tych inicjatyw trwający kryzys finansowy i gospodarczy coraz bardziej uwypuklał słabości systemu zarządzania gospodarczego Unii Europejskiej. Dlatego też coraz intensywniej zaczęto poszukiwać wielopłaszczyznowych rozwiązań i działań, dzięki którym udałoby się w pierwszej kolejności zidentyfikować słabości systemowe, a następnie je wyeliminować lub choćby ograniczyć. Dalsze propozycje w zakresie wzmocnienia koordynacji polityki gospodarczej w Unii Europejskiej, a więc także kolejnej modyfikacji Paktu Stabilności i Wzrostu, zostały przedstawione w Komunikacie Komisji Europejskiej z 12 maja 2010 roku. Następnie w czerwcu tego samego roku w kolejnym komunikacie Komisja doprecyzowała swoje postulaty. Tym razem szczególny nacisk został położony na te kwestie, których wprowadzenie w życie nie wymagałoby zmian na płaszczyźnie traktatów. Działania te wynikały przede wszystkim z faktu, iż nie było w tej kwestii zgody politycznej. Komisja Europejska skoncentrowała się więc na instrumentach polityki budżetowej i konkurencyjności, a jej postulaty odnosiły się do czterech głównych obszarów:

- przestrzegania zapisów Paktu Stabilności i Wzrostu oraz pogłębionej koordynacji polityki fiskalnej - miało to dotyczyć wszystkich państw członkowskich UE,

- nadzoru nad nierównowagami makroekonomicznymi i kwestiami związanymi z konkurencyjnością gospodarki - miało dotyczyć tylko państw członkowskich strefy euro,

- ustanowienia tzw. semestru europejskiego - wszystkie państwa UE,

- opracowania ram zarządzania kryzysowego - państwa strefy euro ${ }^{24}$.

\section{Rysunek 3. Proces koordynacji polityki gospodarczej w ramach Unii Europejskiej}

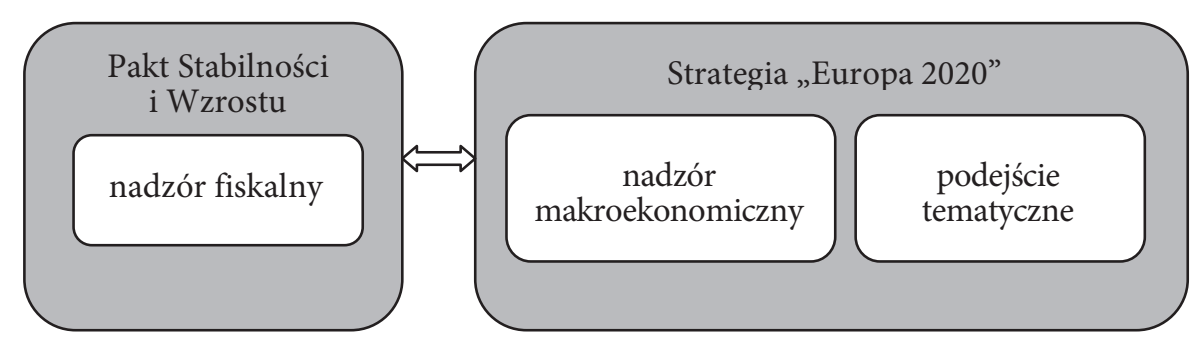

Źródło: Wzmocnienie koordynacji polityki gospodarczej w ramach Unii Europejskiej w świetle propozycji Komisji Europejskiej z dnia 12 maja i 30 czerwca 2010 roku, Narodowy Bank Polski, Departament Zagraniczny, Warszawa, lipiec 2010, s. 3, www.nbp.pl

${ }^{24}$ Por. Wzmocnienie koordynacji polityki gospodarczej w ramach Unii Europejskiej w świetle propozycji Komisji Europejskiej z dnia 12 maja i 30 czerwca 2010 roku, Narodowy Bank Polski, Departament Zagraniczny, Warszawa, lipiec 2010, s. 2, www.nbp.pl 
Komisja Europejska w komunikacie do Parlamentu Europejskiego, Rady Europejskiej, Rady UE, Europejskiego Banku Centralnego, Europejskiego Komitetu Ekonomiczno-Społecznego i Komitetu Regionów z dnia 30 czerwca 2010 roku pt. „Wzmocnienie koordynacji polityki gospodarczej w interesie stabilności, wzrostu gospodarczego i zatrudnienia - narzędzia na rzecz silniejszego zarządzania gospodarczego w UE" przedstawiła syntetyczny opis zmodyfikowanego mechanizmu oceny koordynacji polityki. Równocześnie prace nad środkami na rzecz wzmocnienia zarządzania gospodarczego w Unii Europejskiej toczyły się w powołanej przez marcową Radę Europejską tzw. grupie zadaniowej Hermana van Rompuya, przewodniczącego Rady Europejskiej. Efektem prowadzonych działań było przedstawienie przez Komisję Europejską w dniu 29 września 2010 roku pakietu propozycji legislacyjnych dotyczących unijnych i krajowych reguł fiskalnych oraz nierównowag makroekonomicznych. W dniu 21 października 2010 roku swoje rekomendacje przedstawiła także grupa zadaniowa. Propozycje grupy zostały zatwierdzone przez Radę Europejską podczas posiedzenia w dniach 28-29 października 2010 roku. Nie wymagały one zmian o charakterze traktatowym, jednakże wprowadzenie wielu z nich wymagało przyjęcia aktów prawnych z katalogu wtórnego prawa unijnego ${ }^{25}$. Odpowiednie procedury w tym zakresie zostały uruchomione, a jednocześnie w dniu 26 października 2011 roku wydane zostało oświadczenie ze szczytu państw strefy euro, w którym w załączniku 1 przedstawiono dziesięć środków służących usprawnieniu zarządzania strefą euro ${ }^{26}$.

Równolegle w listopadzie 2011 roku został przyjęty pakiet aktów prawnych w zakresie wzmocnienia zarządzania gospodarczego, składających się na tzw. sześciopak. Przyjęte akty prawne wprowadzają zmiany w odniesieniu do przepisów konstytuujących Pakt Stabilności i Wzrostu - zarówno w części prewencyjnej, jak i korygującej - oraz wprowadzają nową procedurę nadmiernych zakłóceń równowagi makroekonomicznej. Nowe rozwiązania weszły w życie 13 grudnia $2011 \mathrm{roku}^{27}$. W ramach tzw. sześciopaku podjęto także działania na rzecz wzmocnienia nadzoru nad zakłóceniami równowagi makroekonomicznej w Unii Europejskiej. Było to związane z tym, iż w ostatnich dekadach w państwach członkowskich UE powstały

${ }_{25}$ Por. Propozycje Komisji Europejskiej i grupy zadaniowej van Rompuya dotyczące wzmocnienia zarządzania gospodarczego w UE, Narodowy Bank Polski, Departament Zagraniczny, Warszawa, grudzień 2010, s. 1, www.nbp.pl

${ }^{26}$ Oświadczenie ze szczytu państw strefy euro, Bruksela, 26 października 2011 roku, Załącznik 1, s. $11-13$.

27 W dniu 8 listopada 2011 roku nastąpiło formalne przyjęcie przez Radę UE pakietu aktów prawnych składających się na tzw. sześciopak. Formalne przyjęcie było poprzedzone porozumieniem politycznym w ramach Rady UE (co nastąpiło 4 października 2011 roku) oraz akceptacją Parlamentu Europejskiego (w dniu 28 września 2011 roku). Akty zostały opublikowane w Dzienniku Urzędowym UE w dniu 23 listopada 2011 roku. 
istotne różnice w poziomie konkurencyjności i wystąpiły nadmierne zaburzenia równowagi makroekonomicznej. Silne wzajemne powiązania gospodarcze skutkowały często wystąpieniem negatywnych zjawisk w innych państwach członkowskich, tym samym osłabiając odporność całej gospodarki UE na zagrożenia zewnętrzne. Negatywnie oddziaływały one także na prawidłowe funkcjonowanie Unii Gospodarczej i Walutowej, a trwający od 2007 roku kryzys uwypuklił ten problem. Dlatego też w celu wyeliminowania istniejących nierównowag makroekonomicznych oraz przeciwdziałania powstaniu kolejnych stworzony został specjalny mechanizm nadzorczy nad sytuacją makroekonomiczną państw członkowskich UE. Będzie się on opierał na trzech filarach:

- systemie wczesnego ostrzegania,

- stosowaniu ściśle określonych reguł, które zawarte zostały w ramach Procedury Nadmiernych Zakłóceń Równowagi (Excessive Imbalance Procedure - EIP) oraz - rygorystycznym ich egzekwowaniu, wraz z możliwością nałożenia sankcji finansowych na państwa członkowskie należące do strefy euro.

Najnowszą inicjatywą podjętą na forum Unii Europejskiej w walce z kryzysem gospodarczym i zadłużeniowym jest podpisany przez 25 państw (bez Wielkiej Brytanii i Czech) w dniu 2 marca 2012 roku w Brukseli Traktat o stabilności, koordynacji i zarządzaniu w Unii Gospodarczej i Walutowej ${ }^{28}$, który obejmuje tzw. pakt fiskalny - tytuł III Pakt budżetowy. Po raz pierwszy pomysł wprowadzenia paktu fiskalnego dyskutowano na unijnym szczycie 8-9 grudnia 2011 roku. Aby jednak wprowadzić zmiany do obowiązujących traktatów, wymagana jest jednomyślność wszystkich państw członkowskich UE. Na skutek braku zgody Wielkiej Brytanii podjęto decyzję o wykorzystaniu ścieżki międzyrządowej do zaostrzenia dyscypliny budżetowej.

Celem paktu jest zwiększenie dyscypliny budżetowej i wprowadzenie ściślejszego nadzoru w strefie euro, w szczególności dzięki ustanowieniu „zasady zrównoważonego budżetu". Pakt ma charakter międzyrządowy i znajduje się poza wspólnotowym dorobkiem prawnym. Tym samym nie jest on prawem powszechnie obowiązującym w Unii. Oznacza to, że jego przyjęcie lub odrzucenie (brak ratyfikacji) nie może mieć żadnego formalnego wpływu na warunki członkostwa w Unii i zobowiązania członkowskie. W tekście paktu uwzględniono jednak możliwość podjęcia działań w celu włączenia jego postanowień do dorobku traktatowego UE w okresie 5 lat od jego wejścia w życie ${ }^{29}$. Aby pakt wszedł w życie, musi zostać ratyfikowany przez 12 z 17

28 Traktat o stabilności, koordynacji i zarządzaniu w Unii Gospodarczej i Walutowej został ostatecznie uzgodniony na nieformalnym posiedzeniu Rady Europejskiej 30 stycznia 2012 roku, a podpisany 2 marca br. na szczycie Rady Europejskiej w Brukseli, gdzie państwa UE oprócz Wielkiej Brytanii i Czech podpisały traktat międzyrządowy wprowadzający surowsze przepisy budżetowe w strefie euro.

29 Ibidem, art. 16. 
państw strefy euro. Docelową datą jego obowiązywania jest 1 stycznia 2013 roku. Jeśli jednak do tego terminu wymagana większość państw nie ratyfikuje traktatu, to wejdzie on w życie pierwszego dnia miesiąca następującego po dniu złożenia dwunastego dokumentu ratyfikacyjnego przez państwo członkowskie, którego walutą jest euro ${ }^{30}$. Państwa należące do strefy euro są związane traktatem od pierwszego dnia miesiąca następującego po złożeniu przez nie dokumentów ratyfikacyjnych, natomiast państwa będące poza strefą euro są związane tylko postanowieniami tytułów III (Pakt budżetowy) i IV (Koordynacja polityki gospodarczej i konwergencja).

W traktacie ustalono między innymi, że saldo sektora instytucji rządowych i samorządowych musi być zrównoważone lub wykazywać nadwyżkę. Przy czym wymóg uważa się za spełniony, jeżeli roczne saldo strukturalne sektora instytucji rządowych i samorządowych odpowiada celowi średniookresowemu dla danego państwa określonemu w zmienionym Pakcie Stabilności i Wzrostu i dolny pułap deficytu strukturalnego wynosi $0,5 \% \mathrm{PKB}$ w cenach rynkowych $\left(\mathrm{PKB}_{\mathrm{mp}}\right)$. Ustalono także, że państwo może tymczasowo odejść od swojego odpowiedniego celu średniookresowego lub ścieżki dostosowawczej do niego jedynie w wyjątkowych okolicznościach, oznaczających nadzwyczajne zdarzenie, na które państwo nie ma wpływu i które wywiera znaczący wpływ na sytuację finansową sektora instytucji rządowych i samorządowych, lub okresy znacznego pogorszenia koniunktury gospodarczej, o których mowa w zmienionym Pakcie Stabilności i Wzrostu, pod warunkiem, że tymczasowe odchylenia dotyczące danego państwa nie zagrażają stabilności budżetowej w średnim okresie. Ponadto, w przypadku gdy dług sektora instytucji rządowych i samorządowych w stosunku do $\mathrm{PKB}_{\text {mp }}$ pozostaje wyraźnie poniżej $60 \%$ i przy niskim ryzyku utraty długookresowej stabilności finansów publicznych, dolny pułap celu średniookresowego może odpowiadać deficytowi strukturalnemu wynoszącemu najwyżej 1,0\% $\mathrm{PKB}_{\mathrm{mp}}$. Jeżeli natomiast odnotowane zostaną znaczne odstępstwa od tego celu lub od ścieżki korekty, automatycznie ma być uruchomiony mechanizm korygujący. $\mathrm{W}$ takim przypadku dane państwo będzie musiało m.in. podjąć stosowne działania w konkretnym terminie ${ }^{31}$.

Wprowadzono także kryterium konwergencji dla wartości deficytu budżetowego - poniżej 3\% PKB oraz długu publicznego - poniżej 60\% PKB. W sytuacji, gdy dane państwo nie zastosuje się do wytycznych, Komisja Europejska zastrzega sobie możliwość wykorzystania narzędzi nacisku w postaci kar finansowych. W przypadku sporów stron instytucją rozstrzygającą staje się Trybunał Sprawiedliwości UE, który - w przypadku niesłusznie złożonego wniosku - zyskał możliwość obarczenia

\footnotetext{
30 Ibidem, art. 14.

31 Ibidem, art. 3 ust. 1 pkt. a-e oraz art. 3 ust. 3 pkt b.
} 
państwa wnioskującego grzywną o wartości do $0,1 \%$ jego $\mathrm{PKB}^{32}$. Ponadto nowy traktat przewiduje także koordynację i konwergencję polityki gospodarczej. Sprowadza się to do tego, iż jego strony muszą informować o planach emisji długu publicznego oraz dopilnowywać, by ważne reformy polityki gospodarczej zostały wcześniej przedyskutowane, a w stosownych przypadkach - skoordynowane z innymi ${ }^{33}$.

Wśród postanowień traktatu znalazł się również obszar dotyczący zarządzania w strefie euro. Szefowie państw i rządów strefy oraz przewodniczący Komisji Europejskiej mają się spotykać na nieformalnych szczytach strefy euro. Prezes Europejskiego Banku Centralnego ma także być zapraszany do udziału w tych posiedzeniach. Ich uczestnicy mają mianować zwykłą większością głosów przewodniczącego szczytu państw strefy euro w tym samym czasie, gdy Rada Europejska będzie dokonywać wyboru swojego przewodniczącego. Ich kadencje będą takie same - 2,5 roku ${ }^{34}$. Posiedzenia szczytu państw strefy euro mają odbywać się w razie potrzeby, co najmniej dwa razy w roku. Ponadto szefowie państw lub rządów państw, których walutą nie jest euro, a które ratyfikowały traktat, mają uczestniczyć w debatach podczas posiedzeń szczytu państw strefy euro dotyczących konkurencyjności, zmiany ogólnej struktury strefy euro i podstawowych zasad dotyczących tej strefy, które będą obowiązywały w przyszłości. Dodatkowo, w odpowiednich przypadkach i przynajmniej raz w roku, mają oni brać udział w debatach na temat szczegółowych kwestii dotyczących wdrażania Traktatu o stabilności, koordynacji i zarządzaniu w Unii Gospodarczej i Walutowej ${ }^{35}$.

Doświadczenia ostatniego kryzysu finansowego unaoczniły także słabość działających instytucji kontrolnych i nadzorczych w ramach zarówno europejskiego, jak i globalnego systemu finansowego. Dlatego też zdecydowano się na podpisanie porozumienia w sprawie dalszej integracji finansowej. Jego konsekwencją jest obowiązujący od 1 stycznia 2011 roku Europejski System Nadzoru Finansowego. Głównym celem nowego systemu jest zapewnienie właściwego wdrażania przepisów dotyczących sektora finansowego, w sposób umożliwiający zachowanie stabilności finansowej i zapewnienie zaufania do systemu finansowego jako całości oraz odpowiedniej ochrony konsumentów usług finansowych. W skład Europejskiego Systemu Nadzory Finansowego wchodzą:

- Europejska Rada ds. Ryzyka Systemowego (European Systemic Risk Board - ESRB);

- Europejskie Urzędy Nadzoru (European Supervisory Authorities - ESA):

\footnotetext{
32 Ibidem, art. 8.

33 Ibidem, art. 9-11.

34 Ibidem, art. 12 ust. 1.

35 Ibidem, art.12 ust. 3.
} 
- Europejski Urząd Nadzoru Bankowego (European Banking Authority - EBA),

- Europejski Urząd Nadzoru Ubezpieczeń i Pracowniczych Programów Emerytalnych (European Insurance and Occupational Pensions Authority - EIOPA),

- Europejski Urząd Nadzoru Giełd i Papierów Wartościowych (European Securities and Markets Authority - ESMA);

- Wspólny Komitet Europejskich Urzędów Nadzoru (Joint Committee);

- właściwe organy lub organy nadzoru państw członkowskich określone w odpowiednich aktach unijnych ${ }^{36}$.

Na ustabilizowanie sytuacji gospodarczej oraz podtrzymanie zaufania i stabilności sektora bankowego pozytywny wpływ mają także wywrzeć działania zmierzające do zacieśniania współpracy w sektorze bankowym. W oświadczeniu wydanym przez szefów państw lub rządów UE w dniu 26 października 2011 roku w związku ze szczytem państw strefy euro został przedstawiony tzw. konsensus w sprawie pakietu bankowego ${ }^{37}$. Wskazano $\mathrm{w}$ nim na potrzebę zapewnienia finansowania banków w perspektywie średniookresowej, aby uniknąć zapaści kredytowej i chronić dopływ kredytów do gospodarki realnej, a także koordynowania środków służących urzeczywistnianiu tych celów. Ponadto za priorytet uznano poprawę jakości kapitału banków i jego podwyższenia, aby uodpornić się na wstrząsy oraz aby ukazać te działania w sposób wiarygodny i zharmonizowany.

W ramach przyjętych ustaleń stwierdzono także, że aby udzielić bankom bardziej bezpośredniego wsparcia w uzyskiwaniu dostępu do finansowania długookresowego ${ }^{38}$, potrzebne byłyby w stosownych przypadkach gwarancje zabezpieczające zobowiązania banków. Jest to również zasadniczy składnik strategii ograniczającej zakres działań zmniejszających udział finansowania dłużnego. Należy też mieć na uwadze, że w obecnych warunkach rynkowych proste powtórzenie doświadczeń z 2008 roku, kiedy to władze krajowe tworzyły systemy zapewnienia płynności w sposób całkowicie dowolny, może nie być zadowalającym rozwiązaniem. Uznano więc, że potrzebne jest prawdziwie skoordynowane podejście na szczeblu UE w odniesieniu do kryteriów dostępu do systemu, kosztów i warunków. Komisja powinna więc pilnie przeanalizować, wspólnie z Europejskim Urzędem Nadzoru Bankowego (EBA), Europejskim Bankiem Inwestycyjnym (EBI) i Europejskim Bankiem Centralnym (EBC), możliwości osiągnięcia tego celu i przedstawić stosowne sprawozdanie Komitetowi Ekonomiczno-Finansowemu.

\footnotetext{
${ }^{36}$ Por. www.knf.gov.pl (24.08.2011).

37 Stanowi on załącznik do tego oświadczenia.

38 Finansowanie krótkookresowe jest bowiem dostępne poprzez EBC i odpowiednie krajowe banki centralne.
} 
W tzw. pakcie bankowym zaprezentowane zostały także dwa kluczowe elementy odnoszące się do kapitalizacji banków: cel kapitałowy i finansowanie zwiększenia kapitału. Odnośnie do pierwszego z nich potwierdzono, że istnieje szeroki konsensus w kwestii wymogu, by znacząco zwiększyć współczynnik kapitałowy, tak by kapitał najwyższej jakości osiągnął poziom 9\%, po uwzględnieniu wyceny rynkowej zaangażowania w dług państwowy. A to wszystko po to, aby stworzyć tymczasowy bufor, w pełni uzasadniony w tych trudnych i miejmy nadzieję wyjątkowych okolicznościach. Argumentowano również, że taka ostrożna wycena nie będzie miała wpływu na odnośne zasady sprawozdawczości finansowej. Krajowe organy nadzoru, działając pod auspicjami EBA, muszą dopilnować, by plany banków dotyczące wzmocnienia kapitałowego nie doprowadziły do zbyt daleko idącego zmniejszenia finansowania dłużnego. Jednocześnie wyraźnie podkreślono, że należy utrzymać dopływ kredytów do gospodarki realnej i uwzględnić aktualny poziom zaangażowania kredytowego poszczególnych grup, w tym ich jednostek zależnych we wszystkich państwach członkowskich, ze świadomością potrzeby uniknięcia nadmiernej presji na rozszerzanie akcji kredytowej w państwach siedziby lub na rynkach długu państwowego.

W tematyce finansowania zwiększenia kapitału stwierdzono, że banki powinny przede wszystkim korzystać z prywatnych źródeł kapitału, w tym drogą restrukturyzacji i konwersji długu na instrumenty kapitałowe. Powinny one także podlegać ograniczeniom odnośnie do dystrybucji dywidend i wypłat premii do czasu osiągnięcia celu. W razie konieczności rządy poszczególnych państw powinny udzielić wsparcia, a jeśli wsparcie takie nie jest możliwe, dokapitalizowanie powinno być finansowane za pomocą pożyczki z Europejskiego Instrumentu Stabilności Finansowej w przypadku państw strefy euro ${ }^{39}$.

O wielotorowości działań podejmowanych na forum Unii Europejskiej i wśród państw strefy euro mogą świadczyć spotkania na szczycie zajmujące się problematyką stymulacji wzrostu gospodarczego i szerzej rozwoju społeczno-gospodarczego, dzięki czemu można byłoby wpłynąć na poprawę sytuacji na rynku pracy w państwach członkowskich. Odpowiednia dynamika wzrostu w połączeniu z odpowiednią polityką budżetową stanowi także podstawę ograniczenia skali zadłużenia państwa. Tak więc między tymi kategoriami istnieje silne powiązanie o charakterze zwrotnym. Wśród ostatnich przedsięwzięć w tym zakresie na uwagę zasługują Kon-

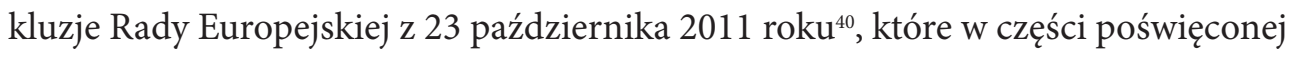
polityce gospodarczej poruszają wiele kwestii zmierzających do poprawy sytuacji zarówno w sferze zmian dochodu narodowego, jak i rynku pracy czy reform struk-

\footnotetext{
39 Oświadczenie szefów państw lub rządów UE, Bruksela, 26 października 2010, s. 2-3.

${ }_{40}$ Konkluzje Rady Europejskiej z 23 października 2011 roku, EUCO 52/1/11 REV 1.
} 
turalnych. Przede wszystkim Rada określiła w nich kilka kluczowych priorytetów w zakresie wewnętrznej polityki gospodarczej, które trzeba zrealizować w krótkiej perspektywie, aby osiągnąć inteligentny, trwały i ekologiczny wzrost gospodarczy sprzyjający włączeniu społecznemu. W związku z tym, iż jednolity rynek ma do odegrania kluczową rolę w zapewnieniu wzrostu gospodarczego i zatrudnienia, należy dołożyć wszelkich starań, by zapewnić osiągnięcie do końca 2012 roku porozumienia w sprawie 12 priorytetowych propozycji określonych w Akcie o jednolitym rynku.

W konkluzjach Rada Europejska zwróciła się także do Komisji, aby ta pilnie przedstawiła harmonogram zakończenia do 2015 roku prac nad jednolitym rynkiem internetowym, traktując priorytetowo wnioski, które mają wspierać w pełni zintegrowany jednolity rynek internetowy przez ułatwienia w prowadzeniu handlu elektronicznego oraz transgraniczne wykorzystywanie usług elektronicznych.

Jednocześnie na państwa członkowskie został nałożony obowiązek dopilnowania, by zalecenia dla poszczególnych państw znalazły pełne odbicie w krajowych decyzjach dotyczących polityki budżetowej i reform strukturalnych, zważywszy na ich fundamentalne znaczenie dla zapewnienia stabilnych finansów publicznych oraz tworzenia miejsc pracy i stymulowania wzrostu gospodarczego. Aby przyczynić się do osiągnięcia tego celu, Rada Europejska zaapelowała, aby Rada przy współpracy z Komisją podjęła działania w celu dopilnowania, by wszystkie działania podejmowane na szczeblu Unii Europejskiej w pełni wspierały wzrost gospodarczy i tworzenie miejsc pracy ${ }^{41}$.

Jeśli idzie o zewnętrzny aspekt polityki gospodarczej, to Europa ma nadal wspierać wolny, uczciwy i otwarty handel, a jednocześnie zabezpieczać swoje interesy w duchu wzajemności i z myślą o wzajemnych korzyściach w odniesieniu do największych gospodarek świata. W ramach stosunków zewnętrznych Unia Europejska może przyjmować różnorodne środki, które mogą przyczynić się do pobudzenia jej potencjału wzrostu, zarówno w perspektywie krótko, jak i długoterminowej ${ }^{42}$.

Pewnym krokiem w kierunku większej spójności i koordynacji polityki gospodarczej jest także oświadczenie członków Rady Europejskiej z 30 stycznia 2012 roku zatytułowane „Ku konsolidacji sprzyjającej wzrostowi i wzrostowi sprzyjającemu tworzeniu miejsc pracy". Szczególne miejsce zostało w nim poświęcone trzem kwestiom: stymulowaniu zatrudnienia szczególnie wśród ludzi młodych, dokończeniu tworzenia jednolitego rynku oraz zwiększeniu finansowania gospodarki, a zwłaszcza MŚP³.

\footnotetext{
${ }^{41}$ Konkluzje Rady Europejskiej z 23 października 2011 roku, EUCO 52/1/11 REV 1, s. 1-2.

42 Ibidem, s. 5.

${ }^{43}$ Oświadczenie członków Rady Europejskiej z 30 stycznia 2012 roku, s. 3.
} 
Resumując, podejmowane inicjatywy należy ocenić pozytywnie. Niemniej nie można zapominać, że w przypadkach wielu z nich ograniczają się one do deklaracji czy oświadczeń. W niektórych przypadkach wydawane są dokumenty, które przynajmniej teoretycznie powinny stanowić gwarancję realizacji zmian ukierunkowanych na długookresową poprawę sytuacji. Doświadczenia ostatnich lat pokazują jednak, że nawet $w$ tym ostatnim przypadku nie stanowią one dostatecznego zabezpieczenia, iż państwa członkowskie będą solidnie wywiązywać się ze swoich zobowiązań. O ile można byłoby oczekiwać, że kryzys zmobilizuje i zachęci do współpracy i wzajemnej kontroli, o tyle praktyka pokazuje inne zachowania. Nasilają się różnice zdań i opinii, coraz trudniej wypracowywać kompromis, co było widoczne przy Traktacie o stabilności, koordynacji i zarządzaniu w Unii Gospodarczej i Walutowej. Niekorzystnie na status podejmowanych decyzji wpływa także ich forma. Coraz częściej dochodzi do obchodzenia podstawowych zasad państw demokratycznych. Z obawy przed niechęcią poszczególnych społeczeństw decyzje zapadają z pominięciem parlamentów czy też instytucji ogólnopaństwowego referendum. Pakty ustalane w wąskich kręgach związanych z władzą wykonawczą z punktu widzenia kanonu negocjacyjnego może i są właściwe czy w sferze oceny efektywne, jednak trudne do zaakceptowania przez społeczeństwo państw członkowskich Unii Europejskiej. Co więcej, taki sposób postępowania zniechęca zarówno obywateli UE, jak i strefy euro do zacieśniania integracji. Wpycha ich jednocześnie w ręce nurtów radykalnych o nacjonalistycznym charakterze. Idea solidarności staje się sloganem, z którego korzystają politycy lub grupy pragnące korzystać z pomocy. Coraz mniej jest zrozumienia dla potrzeby niesienia tej pomocy.

\section{Perspektywy strefy euro w nowych uwarunkowaniach}

Doświadczenia ostatnich lat pokazały, że bardzo trudno jest utrzymać spójność unii walutowej w warunkach braku unifikacji polityki fiskalnej. Dlatego wydaje się niezmiernie istotne, aby podejmować skuteczne działania w tym obszarze. Nie jest jednak powiedziane, że w ramach Unii Gospodarczej i Walutowej udało się to uczynić. O niskiej efektywności inicjatyw obejmujących państwa strefy euro czy szerzej państwa Unii Europejskiej może świadczyć powracający jak bumerang temat kondycji gospodarki i finansów publicznych Grecji. Oficjalnie decyzja o uznaniu tego państwa za bankruta nie została ogłoszona, niemniej jednak zgodnie z przytoczoną wcześniej definicją bankructwa państwa nieformalnie już to nastąpiło. Doszło 
bowiem do redukcji zadłużenia oraz zmian warunków spłaty ${ }^{44}$. Niekorzystnie na ocenę dotychczasowych przedsięwzięć wpływa także sytuacja w Hiszpanii. Przy czym nie tylko w sektorze finansowym, który wymagał w ostatnich miesiącach poważnego zasilenia, ale także na rynku pracy. Narastające bezrobocie, szczególnie dotkliwe i wysokie wśród ludzi młodych, powoduje nie tylko gigantyczne straty w gospodarce w postaci niewykorzystania kluczowego potencjału, ale także przyczynia się do ubożenia społeczeństwa, frustracji i niepokojów społecznych. W takich uwarunkowaniach trudno oczekiwać prowadzenia konsekwentnej, stabilnej i nastawionej na zrównoważenie polityki budżetowej. Coraz częściej padają w związku z tym pytania, czy droga, jaką wybrała Europa w walce z kryzysem gospodarczym i zadłużeniowym w postaci ograniczania wydatków, jest właściwa. Nieco odmienną strategię zastosowały Stany Zjednoczone, które zasilają gospodarkę zarówno przez pakiety fiskalne, jak i ekspansywną politykę pieniężną. Przynajmniej w perspektywie krótkookresowej ta droga wydaje się być nieco lepsza. Co prawda stopa bezrobocia w USA pozostaje wysoka, ale wykazuje tendencję spadkową i jest niższa niż w Unii Europejskiej czy strefie euro. Zgodnie z danymi Międzynarodowego Funduszu Walutowego w latach 2011-1013 wynosiła lub będzie wynosiła według prognoz odpowiednio w USA: 9,0\%, 8,2\% i 7,9\%, natomiast w strefie euro: 10,1\%, 10,9\% i 10,8\% ${ }^{45}$. Szczególnie trudna sytuacja występuje w Hiszpanii, gdzie w II kwartale 2012 roku stopa bezrobocia wyniosła $24,4 \%$, a wśród młodzieży bez pracy jest $53,3 \%$ zdolnych do pracy obywateli ${ }^{46}$. Jednocześnie Stany Zjednoczone odnotowują także wyższą dynamikę wzrostu niż państwa strefy euro. Tendencję tę potwierdzają dane zawarte w tabeli 6 .

Tabela 6. Realny wzrost gospodarczy (w \%)

\begin{tabular}{|l|c|c|c|c|c|c|}
\hline \multirow{2}{*}{} & \multirow{2}{*}{2010} & \multirow{2}{*}{2011} & \multicolumn{3}{|c|}{2012} & \multicolumn{2}{|c|}{2013} \\
\cline { 4 - 7 } & & & kwietniowego & lipcowego & kwietniowego & lipcowego \\
\cline { 4 - 7 } & & 1,7 & 2,1 & 2,0 & 2,4 & 2,3 \\
\hline USA & 3,0 & 1,5 & $-0,3$ & $-0,3$ & 0,9 & 0,7 \\
\hline Strefa euro & 1,9 & 1,5 & &
\end{tabular}

Źródło: World Economic Outlook. Growth Resuming, Dangers Remain, IMF, 04.2012, s. 2; World Economic Outlook Update, 16.07.2012, s. 2.

Nieco korzystniejsze statystyki odnośnie do dynamiki wzrostu przedstawia Eurostat. Według nich dynamika rozwoju Unii Europejskiej w 2011 roku wyosiła średnio

${ }_{44}$ Dnia 15 lutego wierzyciele podarowali Grecji 107 mld euro długu. Por. Kryzys trzyma już pięć lat, "Gazeta Wyborcza" 28.08.2012, s. 22.

45 World Economic Outlook. Growth Resuming, Dangers Remain, IMF, 04.2012, s. 58.

${ }^{46}$ Czy Niemcom starczy cierpliwości, „Gazeta Wyborcza” 28-29.07.2012, s. 7. 
1,5\%, a prognozy na rok 2012 wskazują na zerowy wzrost. Gorzej natomiast sytuacja wygląda w przypadku średniej dla 17 państw strefy euro. Realny wzrost gospodarczy wynosi odpowiednio dla 2011 roku 1,5\%, a dla 2012 roku - 0,3\% ${ }^{47}$. Dokonując oceny strategii, należy także mieć na uwadze koszty, które ona generuje, a więc choćby zmiany w kondycji finansów publicznych. Tu w obu przypadkach uwidoczniło się znaczne pogorszenie sytuacji i wzrost stopnia zadłużenia. Tym samym nie można domniemywać, że droga przysłowiowego zaciskania pasa preferowana przez państwa strefy euro, a także szerzej Unii Europejskiej przynosiła pozytywne rezultaty. Zgodnie z danymi Eurostatu w I kwartale 2012 roku w porównaniu z IV kwartałem 2011 roku wzrosło łączne średnie zadłużenie państw strefy euro z 87,3\% PKB do $88,2 \%$ PKB. Wśród państw Unii Europejskiej również nastąpił wzrost z 82,5\% do $83,4 \% \mathrm{PKB}^{48}$.

$\mathrm{W}$ związku z tym można byłoby wysnuć tezę, że podejmowane działania na rzecz utrzymania - choć tylko teoretycznie i na płaszczyźnie deklaracji czy pewnych dokumentów - progów przyjętych dla deficytu budżetowego oraz długu publicznego ma jedynie polityczny i propagandowo-wizerunkowy wymiar. Politycy mogą się chwalić, że trwają na straży postanowień, które są niezmienne. Rynki natomiast mogą oddawać się iluzji, że obecna sytuacja ma charakter przejściowy. Uzasadnione wydaje się jednak postawienie pytania, jak długo ta fikcja będzie trwać. Ostatnie posunięcia wydają się jedynie grą na czas i przygotowywaniem różnych wariantów w postaci restrukturyzacji - podmiotowej i fundamentalnej - strefy euro, a kto wie czy nawet nie całej integracji europejskiej. Właśnie w tym duchu należy chyba odbierać wypowiedź prezesa Europejskiego Banku Centralnego Mario Draghiego z 2 sierpnia 2012 roku - że euro jest nieodwracalne i że będzie bronił wspólnej waluty ${ }^{49}$. Przeświadczenie o solidności podstaw oraz optymizm co do przyszłości nie powinny skłaniać do tak dramatycznych i wręcz desperackich deklaracji oraz wypowiedzi.

Z jednej strony na konieczność rzeczywistych, a nie tylko pozornych, jak obecnie zmian i reform $\mathrm{w}$ strefie euro, a $\mathrm{z}$ drugiej strony na oderwanie koncepcji politycznych od realnych uwarunkowań wskazują także prognozy dotyczące kształtowania się poziomu długu publicznego w przyszłości. Kluczowe dla funkcjonowania strefy euro gospodarki nie tylko nie odnotują spadku zadłużenia i powrotu do poziomu poniżej $60 \% \mathrm{PKB}$, jak wynika to z przyjętych strategii, paktów czy innych dokumentów, lecz nawet dojdzie do jego wzrostu. Jak wskazuje J. Bacon, w 2015 roku poziom długu publicznego wyniesie we Francji 94,8\% PKB, w Niemczech 81,5\% PKB,

47 Eurostat code: tec00115.

48 Eurostat. Newsrelease. Euroindicators. 111/2012 - 23.07.2012.

49 Euro na wieki wieków, „,Gazeta Wyborcza” 3.08.2012, s. 18. 
w Grecji 158,6\% PKB, we Włoszech 124,7\% PKB, w Portugalii 98,4\% PKB, a w Hiszpanii $94,4 \% \mathrm{PKB}^{50}$. Dane zawarte $\mathrm{w}$ tabeli 7 pokazują, ile lat $\mathrm{w}$ zależności od poziomu wyniku pierwotnego salda budżetu państwa potrwa przywrócenie zadłużenia do poziomu sprzed 2007 roku. Mając na uwadze, że realność zamierzeń przywrócenia równowagi budżetowej przed 2015 rokiem w większości państw Unii Europejskiej, w tym także strefy euro, jest tylko iluzoryczna, a utrzymanie jej w dłuższym okresie co najmniej mało prawdopodobne, to czas niezbędny na przywrócenie zadłużenia sprzed ostatniego kryzysu finansowego i gospodarczego zgodnie z przeprowadzonymi badaniami będzie bardzo długi.

Tabela 7. Wymagany wynik pierwotnego salda budżetu dla przywrócenia poziomu długu sprzed 2007 roku w wybranych państwach strefy euro i USA

\begin{tabular}{|l|c|c|c|}
\hline \multicolumn{1}{|c|}{ Państwo } & Powyżej 5 lat & Powyżej 10 lat & Powyżej 20 lat \\
\hline Austria & 5,1 & 3,0 & 2,0 \\
\hline Francja & 7,3 & 4,3 & 2,8 \\
\hline Niemcy & 5,5 & 3,5 & 2,4 \\
\hline Grecja & 5,4 & 2,8 & 1,5 \\
\hline Irlandia & 11,8 & 5,4 & 2,2 \\
\hline Włochy & 5,1 & 3,4 & 2,5 \\
\hline Holandia & 6,7 & 3,7 & 2,3 \\
\hline Portugalia & 5,7 & 3,1 & 1,8 \\
\hline Hiszpania & 6,1 & 2,9 & 1,3 \\
\hline USA & 8,1 & 4,3 & 2,4 \\
\hline
\end{tabular}

Źródło: Por. T. Gruszecki, op.cit., s. 63.

Wyzwaniem dla państw strefy euro oraz dla większości państw rozwiniętych będzie w następnych latach nie tylko ograniczanie długu jawnego czy oficjalnego, lecz także konsekwencje długu ukrytego, który wynika z przyrzeczonych świadczeń, zwłaszcza emerytalnych i ochrony zdrowia. Ten ostatni rodzaj długu prognozuje się szacunkowo, mając jednak na uwadze występujące w ostatnich latach trendy demograficzne, a także prognozy co do sytuacji demograficznej w państwach rozwiniętych w przyszłości, to już obecnie przewyższa on kilkakrotnie dług jawny. Średnia wielkość ciążących przyszłych zobowiązań w państwach Unii Europejskiej do 2050 roku to $434 \% \mathrm{PKB}^{51}$. Oznacza to więc, że już obecnie państwa te, aby nie powiększać skali swojego zadłużenia, powinny mieć odłożoną wielokrotność swoich rocznych dochodów generowanych w gospodarce. Tymczasem żadne z państw Unii Europejskiej i strefy euro takiej komfortowej sytuacji nie ma.

50 J. Bacon, America’s Shrinnking Fiscal Space, „Seeking Alpha” 5.08.2010.

51 T. Gruszecki, op.cit., s. 56-57. 
Odnosząc się do różnych sposobów wyjścia z nadmiernego zadłużenia państw strefy euro, można domniemywać, że istnieje realne prawdopodobieństwo wykorzystania wszystkich $\mathrm{z}$ nich, a więc restrukturyzacji długu włączając $\mathrm{w}$ to jego redukcję, obniżania kosztów poprzez politykę niskich stóp procentowych oraz wysoką dynamikę wzrostu cen w gospodarce. To, które $\mathrm{z}$ nich będą przeważać $\mathrm{i}$ jakie efekty przyniosą zarówno dla dłużników, jak i wierzycieli, będzie miało fundamentalne znaczenie dla przyszłości strefy euro, także co do tego, czy inicjatywa ta przetrwa obecne zawirowania.

Spośród przytoczonych dróg rozwiązania problemu zadłużenia stosunkowo najwięcej kontrowersji i jednocześnie obaw budzi pierwsza z nich, czyli restrukturyzacja zadłużenia. W praktyce oznacza ona niewypłacalność czyli bankructwo państwa. W wymiarze zewnętrznym skutkuje tym, iż część długu nigdy nie zostanie spłacona lub też że zmianie ulegają warunki spłaty w tym wydłużone zostają terminy spłaty zadłużenia. Jeśli sytuacja ta dotyczy pojedynczego państwa, to oczywiście pojawiają się pewne koszty i utrudnienia, jednakże znacznie poważniejsze problemy występują, gdy dotyczy to grupy państw lub pojedynczych państw, lecz powiązanych ze sobą i tworzących jednolity podmiot gospodarczy. $Z$ tą drugą sytuacją mamy do czynienia w przypadku strefy euro. W związku z narastającymi problemami i ewentualnymi bankructwami państw członkowskich istnieje z jednej strony zagrożenie co do utraty zaufania przez rynki i podmioty nabywające długi państw strefy euro, z drugiej zaś obawa o trwałość porozumienia walutowego, a tym samym wartość wspólnej waluty. Pierwsze bankructwo członka Unii Gospodarczej i Walutowej już nastąpiło, choć oficjalnie nie zostało ogłoszone czy potwierdzone. Potencjał i znaczenie Grecji w porównaniu z całą strefą euro są stosunkowo niewielkie, dlatego też incydent ten poza pewnymi zawirowaniami nie przyczynił się jeszcze do rozpadu strefy. Uwidocznił jednak słabość jej konstrukcji. Znacznie poważniejsza sytuacja wystąpiłaby, gdyby restrukturyzacją długu musiały zostać objęte kolejna państwa, w tym Włochy, Francja czy Hiszpania. A ewentualności tej nie można wykluczyć, tym bardziej że dotychczasowe pakiety pomocowe dla Grecji nie są skuteczne, a dla większej grupy państw mogą być też i niewystarczające. Tym samym nie wypracowano zestawu narzędzi pozwalających w sytuacji zagrożenia opanować problem zadłużenia nawet z wykorzystaniem restrukturyzacji długu. W pewnych okolicznościach może dojść do sytuacji, w której koszty ratowania strefy euro za wszelką cenę mogą być nie do zaakceptowania przez niektóre państwa, a jednocześnie koszty rozpadu strefy mogą już tak nie przerażać niektórych jej członków. Tak więc państwa, które będą radziły sobie lepiej, mogą już nie chcieć dalej pomagać pozostałym członkom Unii Gospodarczej i Walutowej. Tym bardziej że bez zmian w sferze unifikacji fiskalnej nie ma gwarancji utrzymywania dyscypliny budżetowej i stabilności unii walutowej, a więc 
i wspólnej waluty. Dodatkowym zagrożeniem, które obecnie może przekornie stanowić argument na rzecz trwania wspólnej waluty, są silne współzależności i powiązania, w tym przede wszystkim w wymiarze finansowym.

Sposobem na poradzenie sobie $\mathrm{z}$ nadmiernym zadłużeniem jest próba obniżenia kosztów pozyskiwania środków na pokrycie nierównowagi oraz kosztów spłaty zadłużenia poprzez politykę niskich stóp procentowych. Narzędzie to jest także wykorzystywane przez państwa strefy euro. Dodatkowym argumentem na rzecz ekspansywnej polityki pieniężnej jest stymulacja wzrostu gospodarczego niezbędna do rozwiązania problemu nadmiernego zadłużenia. Jednak w tym przypadku coraz częściej pada pytanie, jak długo banki centralne, w tym przypadku Europejski Bank Centralny, mogą utrzymywać tak niskie stopy procentowe, co w praktyce oznacza ujemne realne stopy procentowe. W krótkim okresie strategia ta może przyczynić się do poprawy sytuacji i obniżenia kosztów długu. W dłuższej perspektywie czasowej pozytywna ocena jest już bardziej wątpliwa, szczególnie wówczas, gdy nie towarzyszy jej wzrost akcji kredytowej i ożywienie w realnej sferze gospodarki. Ujemne realne stopy procentowe $\mathrm{w}$ połączeniu $\mathrm{z}$ recesją oznaczają bowiem, że podmioty gospodarcze poszukują innych sposobów ulokowania kapitału i chętniej angażują się w przedsięwzięcia spekulacyjne. W konsekwencji może to prowadzić do powstawania różnych baniek cenowych na rynkach poszczególnych dóbr, jak również do tworzenia nowych, skomplikowanych instrumentów finansowych wykorzystywanych w działalności spekulacyjnej. Jednocześnie w pogoni za wyższą stopą zwrotu z inwestycji podmioty gospodarcze angażują się w coraz bardziej ryzykowne przedsięwzięcia oferowane przez instytucje parabankowe, czy wręcz piramidy finansowe. I tu dostrzegamy, że wszystkie te zdarzenia są bardzo podobne do sytuacji sprzed wybuchu kryzysu finansowego 2007+. Tak więc zwalczając następstwa kryzysu finansowego i gospodarczego w postaci nadmiernego zadłużenia, możemy przyczynić się do wybuchu kolejnego i znacznego pogorszenia sytuacji zamiast jej poprawy.

Ryzyko wybuchu kolejnego kryzysu w związku z akcjami spekulacyjnymi jest tym większe, że trzeci sposób ograniczania kosztów zadłużenia poprzez wyższą dynamikę wzrostu cen jest mało skuteczny. Hiperinflacja jest traktowana jako naturalny sposób zmniejszenia realnej wartości zobowiązań, także państwa, które zostały zaciągnięte w przeszłości, a są spłacane obecnie lub będą spłacane w przyszłości. Rodzi to oczywiście pewne straty w gospodarce, gdyż dochodzi do transferu majątku niewynikającego z przepływu dóbr czy innej aktywności gospodarczej, tym większe, im wyższy poziom inflacji, im dłużej ona trwa oraz im bardziej jest ona nieantycypowalna. Jednakże z punktu widzenia państwa i długu publicznego w warunkach hiperinflacji dochodzi do poprawy sytuacji. Tymczasem, mimo wpompowania 
znacznych kwot zarówno przez Europejski Bank Centralny, jak i System Rezerwy Federalnej w USA czy Bank Anglii, nie doszło do zdecydowanego wzrostu inflacji. Przykładowo FED zasilił system finansowy na kwotę 2,3 bln dol., EBC udzielił pożyczek bankom komercyjnym na kwotę 1,019 bln euro, a Bank Anglii wprowadził do systemu 375 mld funtów. Jednocześnie inflacja w USA wyniosła 1,7\%, w strefie euro 2,4\%, a w Wielkiej Brytanii 2,8\% ${ }^{52}$. Dzieje się tak dlatego, że za pieniądze uzyskane z banków centralnych banki komercyjne i inne instytucje finansowe zamiast zwiększać akcję kredytową, angażują się w działalność spekulacyjną lub nabywają obligacje skarbowe. Jest to szczególnie widoczne na rynkach surowców i żywności. W porównaniu z dniem bessy z 2009 roku ceny pszenicy wzrosły o 95\%, cukru o $85 \%$, soi o $103 \%$, ropy o $165 \%$, miedzi o $144 \%$, a złota o $125 \%$. Jednocześnie w tym samym okresie indeksy giełdowe wzrosły odpowiednio: S\&P 500 (USA) o 108\%, FTSE 100 (Wielka Brytania) o 57\% $\%^{53}$. Relatywnie niska dynamika wzrostu cen obserwowana obecnie nie oznacza oczywiście, że hiperinflacja nie może się pojawić w przyszłości. Niektóre badania wskazują, że istnieje przesunięcie czasowe od pięciu do siedmiu lat między zwiększeniem podaży pieniądza a spiralą inflacyjną. Co więcej, do wzrostu cen w gospodarce, w tym także w państwach strefy euro, może doprowadzić działalność spekulacyjna, jak również inne czynniki choćby w postaci uwarunkowań naturalnych. Ewentualny pozytywny wpływ na problem zadłużenia może objawić się więc z pewnym opóźnieniem, nie należy go jednak wykluczyć. Nie można natomiast zapominać o ewentualnych kosztach dla gospodarki, które temu zjawisku będą towarzyszyć.

\section{Podsumowanie}

Dług publiczny był, jest i będzie, tak jak i sam problem nadmiernego zadłużenia. Wyjątkowość obecnej sytuacji sprowadza się do tego, że dłużnikami z problemami stały się państwa rozwinięte, bezprecedensowa jest też skala zadłużenia. Prognozy na najbliższe dziesięciolecia nie napawają optymizmem m.in. ze względu na marginalizowaną przez lata skalę zadłużenia prywatnego oraz długu ukrytego. Obserwowane w ostatnich latach programy pomocowe i nacjonalizacja długów podmiotów prywatnych bez zmian w systemach kontroli i nadzoru oraz wyciągnięcia konsekwencji wobec winnych wystąpienia zjawisk kryzysowych doprowadziła do

\footnotetext{
52 Potok pieniędzy, strumyczek inflacji, „,Gazeta Wyborcza” 6.08.2012, s. 14.

53 Ibidem.
} 
patowej sytuacji, w której bankructwo grozi państwu, a winowajcy propagują poglądy o słabości i nieudolności państwa i jego instytucji. Dlatego też sytuacja, w jakiej znalazły się państwa Unii Europejskiej, a przede wszystkim strefy euro, jest kolejnym argumentem wskazującym na konieczność konstruktywnej intelektualnej debaty oraz aplikacji ustalonych rozwiązań niezbędnych dla stworzenia nowej architektury w ramach zmodernizowanej współczesnej gospodarki światowej. W tym celu niezbędne jest odejście od demagogii i schematycznego przywiązania do czystego nurtu doktryny ekonomicznej. Niezbędny jest także powrót do idei solidarności - szczególnie w Europie - i podstaw klasycznego kapitalizmu oraz demokracji. Działania podejmowane zarówno w skali globalnej, jak i w odniesieniu do państw Unii Europejskiej czy strefy euro są jedynie kroplą w morzu potrzeb. Wnikliwa analiza inicjatyw podejmowanych na przestrzeni ostatnich lat może sugerować, że albo były one podejmowane na wyrost ze względów ambicjonalnych poszczególnych polityków, albo też były wymuszoną reakcją na zmianę uwarunkowań czy oczekiwań. Niejednokrotnie można je porównać do nieudolnych prób gaszenia pożaru, bez podstawowej wiedzy na temat jego źródeł i bez odpowiednich narzędzi. Być może jedyną skuteczną drogą do osiągnięcia celu, jakim będzie stabilna zrównoważona gospodarka światowa, pozbawiona patologii i nieuzasadnionych nierówności, bez nadmiernej finansyzacji życia gospodarczego i politycznego, w której główna wartość będzie tworzona w realnej gospodarce, jest rewolucja - oby na płaszczyźnie intelektualnej.

\section{Member states of Economic and Monetary Union and the problem of public debt}

Public debt and the increasing indebtedness of states is not a new phenomenon even in the context of bankruptcy of state. In the past we have already experienced internal and external state insolvency. What causes today's increase in preoccupation with external bankruptcy, except for global dimension of debt, is a change in its structure. An increasing number of states uses foreign debt to finance budget and trade imbalances. This tendency is observed among developing as well as developed states, including Economic and Monetary Union member states. The increase in external debt is in large part caused by privet debt which in certain circumstances is transferred to state. The level of total external debt of many Euro Zone member states in relation to GDP is much higher than the level of public debt. These are the reasons that justify the fear for the future of Euro Zone after bankruptcy of some of the member states. What increases the level of fear is the fact that the actions undertaken by European Union and EMU do not cause 
expected results and therefore cannot be judged positively. Paradoxically, some of them have only political and PR dimensions. Politicians may brag about their resolve to defend the once adopted solutions and markets may remain in their illusion that the present situation is only temporary. How long will it last? Last actions seem to be just a game designed to gain some more time to prepare different solutions such as fundamental and subjective restructuring of Euro Zone and - who knows? - maybe even of the European integration as such. The words of European Central Bank president Mario Draghi (August 2, 2012) stressing the fact that there's no turning back from the Euro and that he is going to defend the common currency need to be understood in that context. The belief in the solidarity of states and optimistic outlook for the future should not result in such dramatic and desperate words.

\section{Le problème de la dette publique dans les pays de l'Union économique et monétaire}

La dette publique et le problème de sa croissance n'est pas un phénomène nouveau, même dans le contexte de la faillite de l'État comme entité principale dans les relations internationales. Dans le passé, à plusieurs reprises, nous avons dû faire face à l'insolvabilité de l'État, à la fois interne et externe. À l'heure actuelle, l'intérêt croissant à la faillite externe de l'État découle non seulement de la dimension globale de la dette, mais aussi de la modification de sa structure. De plus en plus de pays financent leurs déséquilibres budgétaires et ceux de la balance commerciale à long terme en contractant des engagements à l'étranger. Cette tendance est observée non seulement dans les pays en développement, mais aussi dans les pays développés, y compris les États membres de l'Union économique et monétaire. Il convient également de noter que l'augmentation de l'ampleur de la dette extérieure est significativement affectée par la dette privée, qui est convertie en dette publique dans certaines circonstances. En outre, dans de nombreux pays de la zone euro, la dette extérieure totale par rapport au PIB est bien au-dessus du niveau de la dette publique. Les préoccupations concernant l'avenir de la zone euro (dans le contexte de la faillite de certains membres) et celle d'autres tentatives similaires d'intégration monétaire, sont raisonnables et justifiées. L'inquiétude augmente, parce que des mesures prises dans le cadre de l'UE et de l'UEM ne donnent pas les résultats escomptés et elles ne peuvent pas être évaluées positivement. Paradoxalement, certaines d'entre elles ont seulement une dimension politique et elles s'inscrivent dans les actions des relations publiques. Les politiciens peuvent se vanter de protéger les solutions déjà adaptées. Les marchés peuvent accepter l'illusion que la 
situation actuelle est temporaire. Cependant, il faut se poser la question suivante: combien de temps cette fiction durera-t-elle? Il semble que les actions récentes aient été prises pour gagner du temps et préparer différentes options sous la forme de restructuration de la zone euro et, peut-être, de l'intégration européenne dans son ensemble. C'est probablement dans ce contexte, dans laquelle la déclaration du président de la Banque centrale européenne Mario Draghi du 2 août 2012 devrait être interprétée. Selon lui, l'euro est irréversible et il défendra la monnaie unique. La croyance en la solidité des fondamentaux et l'optimisme quant à l'avenir ne doivent pas conduire à une telle déclaration dramatique. 